\title{
Late Pleistocene Sedimentation History of the Shirshov Ridge, Bering Sea
}

\author{
M. A. Levitan ${ }^{a}$, T. G. Kuzmina ${ }^{a}$, V. L. Luksha ${ }^{b}$, I. A. Roshchina ${ }^{a}$, K. V. Syromyatnikov ${ }^{a}$, L. Max ${ }^{d}$, \\ D. Nuernberg ${ }^{c}$, J.-R. Riethdorf ${ }^{c}$, R. Tiedemann ${ }^{d}$ \\ ${ }^{a}$ Vernadsky Institute of Geochemistry and Analytical Chemistry, Russian Academy of Sciences, \\ ul. Kosygina 19, Moscow, 119991 Russia \\ e-mail:m-levitan@mail.ru \\ ${ }^{b}$ Faculty of Geology, Moscow State University, Moscow, 119991 Russia \\ ${ }^{c}$ IFM-GEOMAR, Leibniz-Institut für Meereswissenschaften, Wischhofstr. 1-3, D-24148 Kiel, Germany \\ d AWI, Alfred Wegener Institute for Polar and Marine Research, Columbusstrasse, D-27568 Bremerhaven, Germany \\ Received November 08, 2011; accepted December 12, 2011
}

\begin{abstract}
The analysis of the lithology, grain-size distribution, clay minerals, and geochemistry of Upper Pleistocene sediments from the submarine Shirshov Ridge (Bering Sea) showed that the main source area was the Yukon-Tanana terrane of Central Alaska. The sedimentary materials were transported by the Yukon River through Beringia up to the shelf break, where they were entrained by a strong northwestward-flowing sea current. The lithological data revealed several pulses of ice-rafted debris deposition, roughly synchronous with Heinrich events, and periods of weaker bottom-current intensity. Based on the geochemical results, we distinguished intervals of an increase in paleoproductivity and extension of the oxygen minimum zone. The results suggest that there were three stages of deposition driven by glacioeustatic sea-level fluctuations and glacial cycles in Alaska.
\end{abstract}

Keywords: bottom sediments, Shirshov Ridge, Yukon River, Alaska, Bering Strait, grain-size analysis, clay minerals, geochemistry, sedimentation, sea-level, glaciation, paleoproductivity

DOI: $10.1134 / \mathrm{S} 0016702913030051$

\section{INTRODUCTION}

The Bering Sea consists of two nearly equal parts, a shallower northern shelf area with a shelf break at about $150 \mathrm{~m}$ water depth and a deeper southern part, which are separated by a narrow strip of the continental slope and continental rise (Fig. 1). The submarine Shirshov Ridge is located in the deeper western part of the Bering Sea. It extends almost north-south for about $700 \mathrm{~km}$ separating the Komandorsky (to the west) and Aleutian (to the east) basins and has a width of about $200 \mathrm{~km}$ in the north and $20 \mathrm{~km}$ in the south [1]. The ridge has two topographic highs, which rise above the basin bottom from $2000-2500 \mathrm{~m}$ in the north to $1000-2000 \mathrm{~m}$ in the south. The water depth ranges along the ridge crest from $233 \mathrm{~m}$ in the north to $2800 \mathrm{~m}$ in the south. The slope angle varies from $1.5^{\circ}-4^{\circ}$ in the north and up to $10^{\circ}$ in the south. The ridge is separated from the continental slope (abreast the Cape Olyutorsky) by a transverse fault and cannot be considered as its geological extension [2].

Nowadays, the northern part of the ridge (to approximately $57^{\circ} \mathrm{N}$ ) constitutes together with the continental shelf and slope an area where terrigenous sedimentation predominates, whereas its southern portion with the deep-sea basins and the Bowers Ridge is dominated by diatom ooze sediments $[3,4]$. It should be noted that two zones of low-silica diatom oozes were encountered in the center of Russia's part of the shelf and southward from St. Matthew Island [1].

Recent studies demonstrated that the river terrigenous flux to the existing sediment budgets of the Bering Sea is 157.1 million tons per year (9/10 of which is supplied by the Yukon River off Alaska), and the coastal abrasion supply is 200-400 million tons per year (dominated by Asian coastal material). It is known that material produced by coastal abrasion is deposited near the coastline. Existing surface water circulation patterns (Fig. 1) indicate that the annual sediment flux from the Bering Sea through the Bering Strait (maximum $58 \mathrm{~m}$ deep) to the Chukchi Sea ranges from 112 to 158 million tons [1]. The seasonal ice cover persists in the northern part of the sea for at least five months per year and for seven months in the extreme north [1]. The southern part of the sea is presently almost ice-free. The annual primary production of the basin is estimated as $150-500 \mathrm{~g} \mathrm{C} / \mathrm{m}^{2}$ on the continental margin and $50-$ $100 \mathrm{~g} \mathrm{C} / \mathrm{m}^{2}$ in the deep sea [5]. In the northern part of the deep Bering Sea, the oxygen minimum zone pres- 


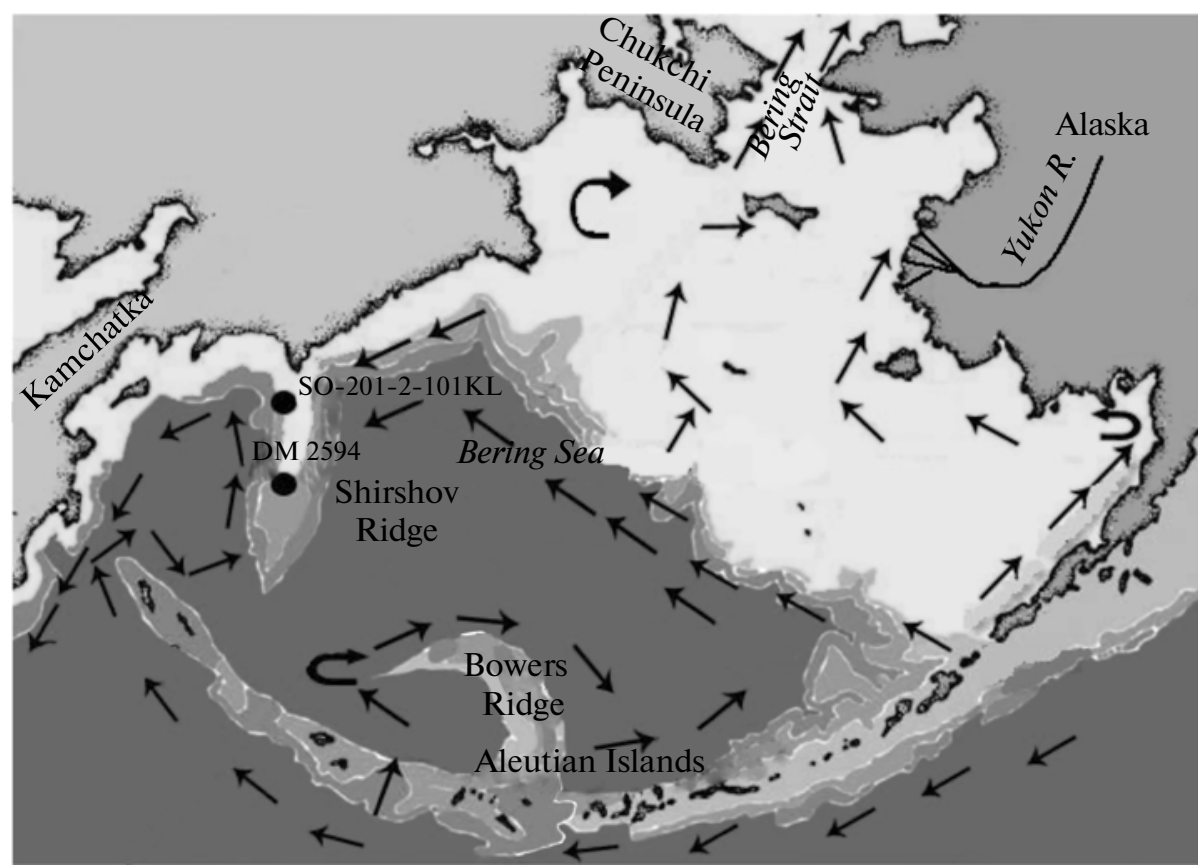

Fig. 1. Location of the cored section at the Shirshov Ridge and present-day surface circulation in the Bering Sea [46].

ently develops at water depths of 380-1200 m, being particularly distinct between 600 and $1100 \mathrm{~m} \mathrm{[6].}$

The history of Quaternary sedimentation at the Shirshov Ridge is still poorly understood. The only data available in the literature are those on sediment core DM 2594 [7] from the southern edge of the ridge (Fig. 1). The core records revealed that terrigenous sedimentation occurred at the end of Marine Isotopic Stage (MIS) 3, during MIS 2, and at the beginning (up to $9.07 \mathrm{cal}$. kyr BP) of MIS 1 and was followed by a period of diatom ooze deposition. The lithological and mineralogical boundaries coincide, indicating a change in provenance from the areas adjoining the coast of the Bering Sea (primarily, Alaska) to presumably the Aleutians [3].

A $1815 \mathrm{~cm}$-long sediment core (S0201-2-101-KL) was recovered from the northern slope of the Shirshov Ridge at a water depth of $607 \mathrm{~m}$ during the R/V "Sonne" (Germany) cruise of 2009 carried out within the framework of the German-Russian KALMAR project (Fig. 1). We report the results of the study of the sediment core with emphasis on the history of terrigenous sedimentation. The investigation of other cores recovered during this project is under way, and only preliminary stratigraphic and paleooceanological data are now available [8-11].

\section{FACTUAL MATERIAL AND METHODS}

Shipboard studies included visual core description (R. Tiedemann and D. Nuernberg), physical property logs, and color core photographs (R. Tiedemann, D. Nuernberg, L. Max, and J.-R. Riethdorf) [6]. The same authors were responsible for the stratigraphic subdivision of the sediment core. The upper part of the core was used for the accelerator mass spectrometric radiocarbon dating of the planktonic foraminifera. An age model for the cored section [11] was constructed based on AMS radiocarbon dates and correlation with color reflectance logs (color $\left.b^{*}\right), \delta^{18} \mathrm{O}$ records, and XRF $\mathrm{Ca} / \mathrm{Ti}$ scanning data (Table 1 ).

The core was subsampled for analysis at $15-20-\mathrm{cm}$ intervals in Moscow. Shore-based laboratory studies included grain-size analysis (L.A. Zadorina, Vernadsky Institute of Geochemistry and Analytical Chemistry, Russian Academy of Sciences), bulk sediment (M.A. Levitan and K.V. Syromyatnikov) and clay mineral composition of the $<2-\mu \mathrm{m}$ size fraction (V.L. Luksha), chemical analysis by X-ray fluorescence (I.A. Roshchina), and correlation and factor analysis of data on the grain size, mineralogy, and chemical composition of sediments (T.G. Kuzmina).

In wet-sieve analysis, the boundaries between gravel, sand, silt, and clay were placed at values of 2, 0.063, and $0.002 \mathrm{~mm}$, respectively. The clay minerals were analyzed on a DRON-3M diffractometer with a copper anode, using the technique described by Biscaye [12]. Bottom sediments used in XRF analysis were not washed to remove sea salt, following the procedure described in detail by I.A. Roshchina [13]. A total of 90 sediment samples were analyzed. 


\section{RESULTS AND DISCUSSION}

Lithology. Based on the component analysis data, all the samples used in this study are terrigenous sediments. The grain-size results are presented in Table 2. Based on these data, three major types of lithologies were recognized: dominant, minor, and rare. Dominant lithologies are silts and clayey silts containing less than $10 \%$ of the $>0.063-\mathrm{mm}$ size fraction. Minor lithologies are silts with some amounts of sand $(10-16 \%$ of the $>0.063-\mathrm{mm}$ size fraction). Rare lithologies are silty sands, mictites, and sandy-clayey silts, in which the $>0.063-\mathrm{mm}$ size fraction is higher than $16 \%$ reaching a maximum value of $60 \%$ (1675-1570 cm depth interval). Interestingly, almost all maxima in the distribution of this fraction are reflected in magnetic susceptibility values (Fig. 2), suggesting that at least part of this fraction is represented by ferrimagnetic particles. A few peaks in the distribution of the sand fraction (1674-1675, 1654-1655, 1494$1495 \mathrm{~cm}$ ) show no correlation with the susceptibility maxima. This is indicative of a high proportion of coarser gravel material.

The component analysis of bulk sediments shows that light-colored and clay minerals dominate the sediment $(27-30 \%$ each), with $11-18 \%$ each of colored minerals and rock fragments. Opaque minerals, volcanic glasses, remains of siliceous (diatoms and siliceous sponge spicules) and carbonate (bivalves, foraminifera, and calcareous nannofossils) organisms occur in trace amounts up to a few percent. Some grains contain fragments of radiolarian tests and authigenic pyrite occurring either as isolated grains or framboids within diatom frustules. The volcanic glasses in the sediments are dominated by green varieties above $920 \mathrm{~cm}$ and brown varieties below this level. Except for the above-mentioned interval of abundant sand fractions, all the maxima in the $>0.063-\mathrm{mm}$ size fraction can be accounted for by the contribution of ice-rafted material. The samples corresponding to these maxima contain wellrounded sand-sized quartz grains, which may indicate their possible transport by one-year ice.

Diagrams showing the relationship between the clay and sand versus silt fractions are of certain interest (Fig. 3). Some samples contain more than $70 \%$ silt, irrespective of the proportion of sand (Fig. 3a). Nevertheless, a negative correlation between the fractions is quite evident within the entire sample set $\left(R^{2}=0.7263\right)$. These relations may indicate different mechanisms of transportation and deposition of both fractions. For much of the section, the sand-sized terrigenous particles may have been rafted by sea ice (occasionally icebergs?), but the silts must have been transported by rivers. However, the silt and sand fractions of samples from the sandy interval also show a negative correlation.
Table 1. The age model of sediment core SO201-2-101KL, modified after [11]

\begin{tabular}{|c|c|c|c|}
\hline Depth, cm & $\begin{array}{c}\text { Calendar age, } \\
\text { kyr BP }\end{array}$ & $\begin{array}{l}\text { Analytical } \\
\text { technique }\end{array}$ & $\begin{array}{c}\text { Marine } \\
\text { isotopic stage } \\
\text { (MIS) }\end{array}$ \\
\hline 4 & 12.9 & 1 & 2 \\
\hline 10.5 & 13.56 & 2 & 2 \\
\hline 41 & 14.6 & 3 & 2 \\
\hline 67 & 15.4 & 3 & 2 \\
\hline 90.5 & 17.25 & 2 & 2 \\
\hline 190.5 & 25.74 & 2 & 2 \\
\hline 234 & 28.6 & 3 & 3 \\
\hline 249 & 30.3 & 3 & 3 \\
\hline 260.5 & 32.0 & 2 & 3 \\
\hline 274 & 33.5 & 1 & 3 \\
\hline 280 & 35.1 & 1 & 3 \\
\hline 284 & 35.7 & 1 & 3 \\
\hline 302 & 36.9 & 1 & 3 \\
\hline 349 & 39.7 & 1 & 3 \\
\hline 387 & 43.1 & 1 & 3 \\
\hline 454 & 46.9 & 1 & 3 \\
\hline 514 & 51.6 & 1 & 3 \\
\hline 650 & 56.6 & 1 & 3 \\
\hline 685 & 57.8 & 1 & 3 \\
\hline 723 & 59.7 & 1 & 3 \\
\hline 799 & 64.1 & 1 & 4 \\
\hline 923 & 71.7 & 1 & 4 \\
\hline 1004 & 76.4 & 3 & 5 \\
\hline 1023 & 77.8 & 3 & 5 \\
\hline 1092 & 84.4 & 1 & 5 \\
\hline 1142 & 89.1 & 1 & 5 \\
\hline 1236 & 94.5 & 3 & 5 \\
\hline 1301 & 103.5 & 3 & 5 \\
\hline 1526 & 116.0 & 4 & 5 \\
\hline 1591 & 126.0 & 4 & 5 \\
\hline 1611 & 129.0 & 4 & 5 \\
\hline 1631 & 135.0 & 4 & 6 \\
\hline 1646 & 140.0 & 4 & 6 \\
\hline 1762 & 150.0 & 4 & 6 \\
\hline 1816 & 156.0 & 4 & 6 \\
\hline
\end{tabular}

Note: 1 , age determined by correlation with reference sediment column SO201-2-85KL using XRF $\mathrm{Ca} / \mathrm{Ti}$ core scanning data; 2 , AMS ${ }^{14} \mathrm{C} ; 3$, correlation of the $b^{*}$ values determined from color reflectance in reference column NGRIP; and 4 , correlation of $\delta^{18} \mathrm{O}$ values with those in reference column LR04. 
Table 2. Grain-size determinations in bottom sediments (fraction size in mm, fraction content in wt \%)

\begin{tabular}{|c|c|c|c|c|c|c|c|c|c|c|}
\hline Interval, $\mathrm{cm}$ & $>2$ & $2-1$ & $1-0.5$ & $0.5-0.25$ & $0.25-0.125$ & $0.125-0.063$ & $0.063-0.01$ & $0.01-0.002$ & $<0.002$ & Lithotype \\
\hline $34-35$ & 0.02 & 0.01 & 0.01 & 0.04 & 0.17 & 0.75 & 35.47 & 35.63 & 27.91 & Silt \\
\hline $54-55$ & 0.04 & 0.13 & 0.04 & 0.08 & 0.71 & 1.38 & 38.29 & 29.93 & 29.43 & Silt \\
\hline $74-76$ & - & - & 0.05 & 0.08 & 0.55 & 1.04 & 41.26 & 38.21 & 18.8 & Silt \\
\hline $94-95$ & - & 0.01 & 0.03 & 1.05 & 3.53 & 2.16 & 30.56 & 28.06 & 34.60 & Clayey silt \\
\hline $114-115$ & 0.13 & 0.03 & 0.13 & 0.19 & 3.83 & 4.46 & 32.24 & 32.46 & 26.53 & Silt \\
\hline $134-135$ & 0.06 & 0.01 & 0.09 & 0.14 & 1.55 & 2.55 & 33.94 & 33.25 & 28.41 & Silt \\
\hline $154-155$ & - & 0.03 & 0.07 & 0.14 & 2.36 & 2.60 & 33.04 & 32.69 & 29.06 & Silt \\
\hline $174-175$ & - & 0.07 & 0.03 & 0.14 & 2.50 & 2.92 & 36.77 & 32.01 & 25.56 & Silt \\
\hline $214-215$ & - & 0.51 & 0.11 & 0.16 & 2.50 & 3.62 & 34.08 & 31.76 & 27.26 & Silt \\
\hline $234-235$ & 0.39 & 0.10 & 0.10 & 0.26 & 6.18 & 5.99 & 26.24 & 32.62 & 28.13 & Silt with sand \\
\hline $254-255$ & 1.40 & 0.02 & 0.04 & 0.19 & 3.22 & 5.15 & 35.09 & 29.43 & 25.47 & Silt with sand \\
\hline $274-275$ & 0.65 & 0.11 & 0.12 & 0.34 & 4.87 & 4.20 & 33.13 & 30.91 & 25.67 & Silt with sand \\
\hline $294-295$ & 0.31 & 0.01 & 0.08 & 0.23 & 4.36 & 6.17 & 33.51 & 31.27 & 24.06 & Silt with sand \\
\hline $314-315$ & 0.12 & 0.15 & 0.15 & 0.27 & 5.08 & 6.16 & 35.89 & 33.08 & 19.10 & Silt with sand \\
\hline $354-355$ & 0.35 & 0.13 & 0.13 & 0.17 & 1.40 & 2.14 & 37.22 & 29.84 & 28.62 & Silt \\
\hline $374-375$ & 0.10 & 0.10 & 0.10 & 0.13 & 2.46 & 2.03 & 39.39 & 28.03 & 27.66 & Silt \\
\hline $394-395$ & - & 0.25 & 0.04 & 0.17 & 2.08 & 2.95 & 38.09 & 23.16 & 33.26 & Clayey silt \\
\hline $414-415$ & - & 0.04 & 0.04 & 0.09 & 0.94 & 2.69 & 32.99 & 33.89 & 29.33 & Silt \\
\hline $434-435$ & 0.41 & 0.22 & 0.10 & 0.16 & 1.05 & 3.84 & 32.55 & 32.77 & 28.91 & Silt \\
\hline $454-455$ & - & 0.34 & 0.17 & 0.29 & 7.33 & 7.46 & 29.96 & 26.80 & 27.64 & Silt with sand \\
\hline $474-475$ & - & 0.18 & 0.22 & 0.26 & 1.83 & 3.95 & 33.50 & 33.72 & 26.34 & Silt \\
\hline $494-495$ & - & 0.04 & 0.06 & 0.08 & 0.50 & 2.50 & 34.93 & 32.51 & 29.38 & Silt \\
\hline $514-515$ & 0.67 & 0.29 & 0.24 & 0.58 & 2.06 & 3.93 & 32.57 & 30.50 & 29.16 & Silt \\
\hline $534-535$ & - & 0.05 & 0.09 & 0.38 & 0.66 & 3.61 & 21.75 & 38.51 & 34.95 & Clayey silt \\
\hline $554-555$ & - & 0.02 & 0.05 & 0.40 & 0.94 & 3.67 & 32.97 & 32.37 & 29.39 & Silt \\
\hline $574-575$ & - & 0.11 & 0.08 & 0.27 & 0.65 & 2.89 & 37.23 & 30.21 & 28.57 & Silt \\
\hline $594-595$ & - & 0.08 & 0.04 & 0.08 & 0.65 & 2.59 & 33.90 & 31.55 & 31.11 & Clayey silt \\
\hline $614-615$ & - & - & 0.01 & 0.21 & 1.54 & 2.28 & 39.91 & 24.51 & 31.53 & Clayey silt \\
\hline $634-635$ & - & - & 0.06 & 0.08 & 1.31 & 2.39 & 35.92 & 31.87 & 28.37 & Silt \\
\hline $654-655$ & - & 0.01 & 0.02 & 0.05 & 0.33 & 1.35 & 36.23 & 34.51 & 27.51 & Silt \\
\hline $674-675$ & - & - & 0.05 & 0.20 & 0.66 & 2.16 & 28.97 & 36.51 & 31.46 & Clayey silt \\
\hline $694-695$ & 0.47 & - & 0.06 & 0.08 & 0.67 & 1.24 & 36.54 & 31.44 & 29.5 & Silt \\
\hline $714-715$ & - & 0.05 & 0.01 & 0.17 & 1.29 & 1.71 & 34.28 & 32.25 & 30.23 & Clayey silt \\
\hline $734-735$ & - & - & 0.09 & 0.32 & 4.22 & 4.59 & 34.59 & 26.31 & 29.89 & Silt \\
\hline $754-755$ & - & 0.19 & 0.13 & 0.15 & 2.00 & 2.3 & 33.60 & 30.39 & 31.25 & Clayey silt \\
\hline $774-775$ & - & - & 0.04 & 0.07 & 1.00 & 1.58 & 35.85 & 31.04 & 30.41 & Clayey silt \\
\hline $794-795$ & 0.37 & 0.09 & 0.08 & 0.06 & 0.31 & 0.97 & 36.28 & 33.27 & 28.57 & Silt \\
\hline $814-815$ & - & 0.40 & 0.24 & 0.24 & 4.05 & 2.94 & 23.65 & 37.59 & 30.88 & Clayey silt \\
\hline $841-842$ & - & - & 0.05 & 0.23 & 1.82 & 3.58 & 34.36 & 32.71 & 27.25 & Silt \\
\hline $854-855$ & 2.53 & 0.55 & 2.09 & 0.23 & 3.05 & 4.52 & 29.41 & 31.44 & 26.19 & Silt with sand \\
\hline $874-875$ & - & 0.16 & 0.10 & 0.14 & 1.89 & 1.27 & 34.73 & 31.41 & 30.24 & Clayey silt \\
\hline $894-895$ & - & - & 0.13 & 0.18 & 1.24 & 2.4 & 34.26 & 32.28 & 29.51 & Silt \\
\hline $921-922$ & 0.87 & - & 0.18 & 0.11 & 0.73 & 1.9 & 36.70 & 32.11 & 27.4 & Silt \\
\hline $934-935$ & 0.09 & - & 0.03 & 0.10 & 1.05 & 2.55 & 35.23 & 33.28 & 27.68 & Silt \\
\hline 954-955 & - & - & 0.06 & 0.09 & 0.94 & 2.34 & 38.00 & 28.65 & 29.92 & Silt \\
\hline $974-975$ & - & - & 0.04 & 0.07 & 0.36 & 1.01 & 35.76 & 32.24 & 30.52 & Clayey silt \\
\hline 994-995 & - & - & 0.04 & 0.05 & 0.49 & 1.17 & 36.16 & 33.29 & 28.81 & Silt \\
\hline $1016-1017$ & - & 0.12 & 0.67 & 0.36 & 2.57 & 3.14 & 33.31 & 31.05 & 28.79 & Silt \\
\hline
\end{tabular}


Table 2. (Contd.)

\begin{tabular}{|c|c|c|c|c|c|c|c|c|c|c|}
\hline Interval, $\mathrm{cm}$ & $>2$ & $2-1$ & $1-0.5$ & $0.5-0.25$ & $0.25-0.125$ & $0.125-0.063$ & $0.063-0.01$ & $0.01-0.002$ & $<0.002$ & Lithotype \\
\hline $1034-1035$ & - & - & 0.03 & 0.07 & 0.67 & 1.4 & 34.48 & 34.70 & 28.66 & Silt \\
\hline 1054-1055 & - & - & 0.07 & 0.19 & 1.42 & 3.14 & 37.48 & 30.18 & 27.51 & Silt \\
\hline $1074-1075$ & - & - & 0.19 & 0.22 & 2.32 & 4.64 & 37.70 & 28.43 & 26.51 & Silt \\
\hline 1094-1095 & - & 0.10 & 0.11 & 0.14 & 1.4 & 3.06 & 41.03 & 27.51 & 26.65 & Silt \\
\hline 1114-1115 & - & - & 0.20 & 0.14 & 3.44 & 5.18 & 32.73 & 28.64 & 29.68 & Silt \\
\hline $1134-1135$ & 0.02 & 0.04 & 0.10 & 0.11 & 2.23 & 3.04 & 35.32 & 33.27 & 25.86 & Silt \\
\hline $1154-1155$ & - & 0.33 & 0.13 & 0.13 & 1.94 & 3.01 & 38.01 & 29.73 & 26.72 & Silt \\
\hline $1174-1175$ & - & 0.25 & 0.08 & 0.17 & 2.03 & 5.06 & 32.79 & 29.06 & 30.55 & Clayey silt \\
\hline 1194-1195 & - & - & 0.12 & 0.12 & 1.94 & 4.25 & 35.50 & 27.00 & 31.07 & Clayey silt \\
\hline $1214-1215$ & - & - & 0.08 & 0.12 & 1.12 & 5.22 & 35.38 & 35.54 & 22.54 & Silt \\
\hline $1234-1235$ & - & 0.03 & 0.03 & 0.06 & 0.71 & 3.43 & 35.44 & 30.06 & 30.24 & Clayey silt \\
\hline $1254-1255$ & - & 0.12 & 0.03 & 0.06 & 0.90 & 2.7 & 35.96 & 31.46 & 28.77 & Silt \\
\hline $1274-1275$ & - & - & 0.06 & 0.07 & 0.22 & 0.87 & 37.67 & 34.50 & 26.62 & Silt \\
\hline $1294-1295$ & 0.12 & - & 0.08 & 0.08 & 0.15 & 0.46 & 42.62 & 35.53 & 20.96 & Silt \\
\hline $1314-1315$ & - & 0.02 & 0.06 & 0.09 & 0.90 & 2.81 & 36.89 & 31.44 & 27.79 & Silt \\
\hline 1334-1335 & - & 0.01 & 0.02 & 0.08 & 1.48 & 1.94 & 36.88 & 30.97 & 28.63 & Silt \\
\hline 1354-1355 & 0.08 & 0.08 & 0.12 & 0.15 & 0.71 & 2.3 & 33.86 & 33.47 & 29.22 & Silt \\
\hline $1374-1375$ & - & 0.03 & 0.06 & 0.10 & 0.58 & 1.55 & 35.26 & 34.46 & 27.95 & Silt \\
\hline 1394-1395 & 0.05 & 0.09 & 0.19 & 0.42 & 1.35 & 1.68 & 51.63 & 35.62 & 8.96 & Silt \\
\hline $1414-1415$ & 0.04 & 0.31 & 0.09 & 0.22 & 0.84 & 1.95 & 37.14 & 33.14 & 26.26 & Silt \\
\hline $1434-1435$ & 1.96 & 0.33 & 0.24 & 0.29 & 1.0 & 1.2 & 35.53 & 35.72 & 23.72 & Silt \\
\hline $1454-1455$ & 1.28 & 0.04 & 0.24 & 0.20 & 0.52 & 0.72 & 33.38 & 33.63 & 30.0 & Clayey silt \\
\hline $1474-1475$ & - & 0.20 & 0.20 & 0.20 & 0.72 & 0.72 & 39.25 & 35.64 & 23.07 & Silt \\
\hline 1494-1495 & 7.62 & 0.82 & 0.45 & 0.41 & 1.03 & 1.94 & 31.23 & 30.12 & 26.37 & Silt with sand \\
\hline $1514-1515$ & 0.78 & 0.16 & 0.20 & 0.33 & 0.90 & 0.61 & 34.29 & 33.88 & 28.84 & Silt \\
\hline $1534-1535$ & 0.39 & 0.24 & 0.58 & 0.34 & 0.83 & 1.85 & 39.18 & 31.7 & 24.89 & Silt \\
\hline 1554-1555 & 2.28 & 0.11 & 0.11 & 0.42 & 0.69 & 1.91 & 36.06 & 32.08 & 26.34 & Silt \\
\hline $1574-1575$ & 7.75 & 1.09 & 0.76 & 1.15 & 32.26 & 20.52 & 14.68 & 11.3 & 10.48 & Silt with sand \\
\hline $1594-1595$ & - & 0.25 & 0.32 & 1.08 & 36.61 & 12.48 & 20.01 & 16.09 & 13.17 & Silt with sand \\
\hline $1614-1615$ & - & 0.05 & 0.14 & 0.34 & 18.34 & 6.03 & 32.77 & 22.25 & 20.08 & Mictite \\
\hline $1634-1635$ & - & 0.45 & 0.54 & 0.49 & 4.79 & 7.07 & 36.76 & 25.58 & 24.33 & Silt and sand \\
\hline $1654-1655$ & 0.29 & 0.06 & 0.23 & 0.69 & 11.0 & 6.77 & 31.09 & 28.55 & 21.31 & Silt and sand \\
\hline $1674-1675$ & - & 0.10 & 0.10 & 0.34 & 15.27 & 2.5 & 32.50 & 24.91 & 24.28 & Silt and sand \\
\hline 1694-1695 & 0.16 & 0.16 & 0.32 & 0.16 & 2.26 & 9.69 & 38.29 & 25.69 & 23.26 & Silt with sand \\
\hline 1714-1715 & - & 0.05 & 0.14 & 0.24 & 1.34 & 4.20 & 38.47 & 31.89 & 23.68 & Silt \\
\hline $1734-1735$ & - & 0.04 & 0.09 & 0.13 & 1.45 & 5.26 & 37.82 & 29.91 & 25.30 & Silt \\
\hline 1754-1755 & - & - & 0.10 & 0.10 & 0.50 & 2.48 & 39.15 & 30.72 & 26.96 & Silt \\
\hline $1774-1775$ & - & 0.19 & 0.24 & 0.94 & 2.30 & 5.17 & 35.65 & 30.67 & 24.84 & Silt \\
\hline 1794-1795 & - & 0.05 & 0.09 & 0.19 & 1.59 & 4.26 & 36.27 & 30.55 & 26.99 & Silt \\
\hline 1814-1815 & - & 0.12 & 0.09 & 0.12 & 1.28 & 5.72 & 40.56 & 29.71 & 22.41 & Silt \\
\hline
\end{tabular}

Note: Blank entry denotes the absence of the fraction. 


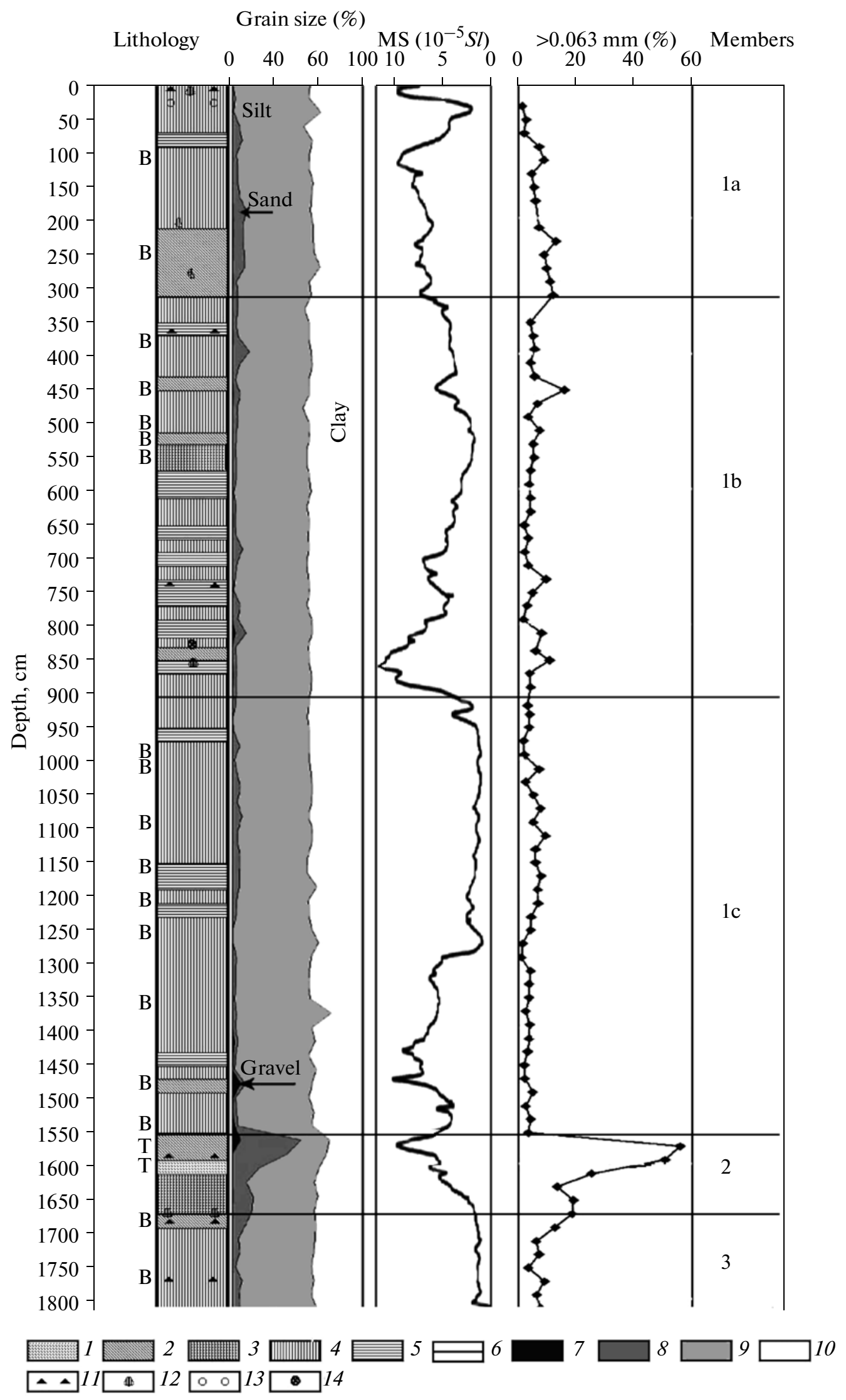



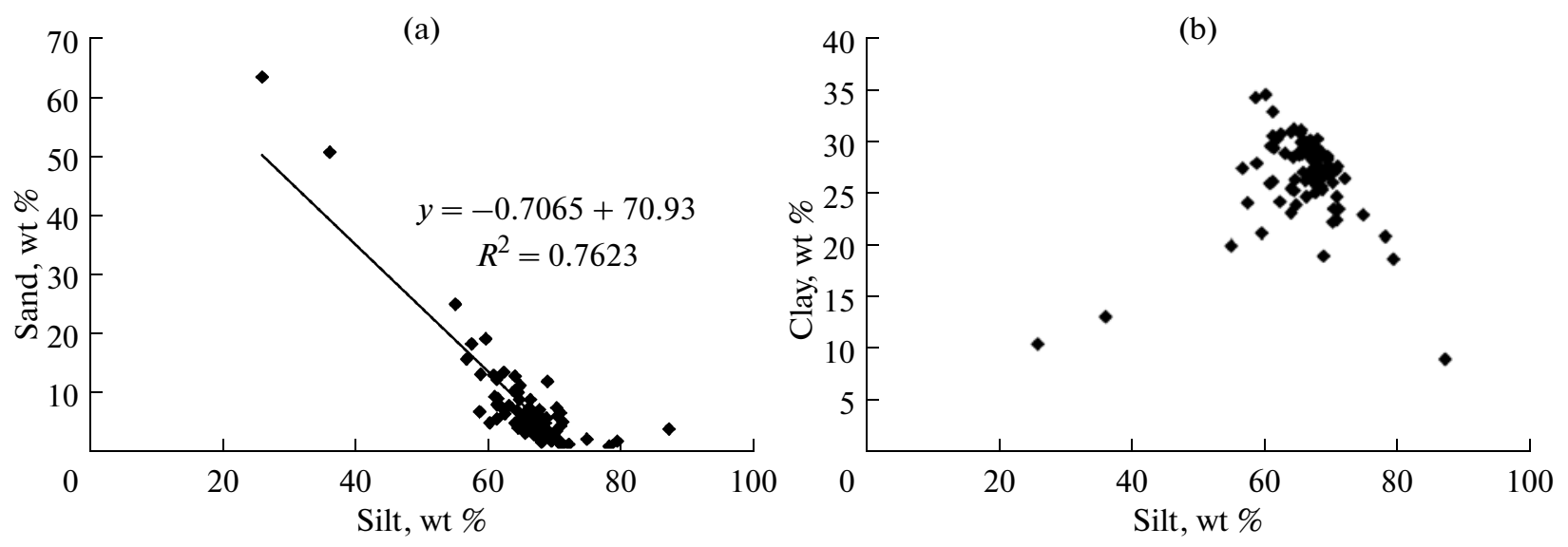

Fig. 3. Relationship between grain-size fractions in the sediments.

The relationship between silt and clay is of interest as well (Fig. 3b). It is evident that a few samples taken entirely from the sandy interval show a positive correlation between clay and silt, whereas the majority of other samples show a negative correlation. The negative correlation likely indicates washing out of the fine-grained clay fraction by bottom currents. Similar situations were also described on the slopes of the Lomonosov Ridge in the central Arctic Ocean [14] and the continental slope of the Kara Sea [15]. Variations in the silt/clay ratio can potentially be used to provide a semiquantitative estimate of fluctuations of the bottom currents. Most of the samples have a silt/clay ratio of 2.0-3.0; values higher than 3.0 suggest an increase in bottom current velocity, which is characteristics of layers (from bottom to top) at 74, 314, 1214, 1294, 1394, 1434, 1474, and $1814 \mathrm{~cm}$. Silt/clay ratios of 1.0-2.0 correspond to a decrease in bottom current velocity at 394, 534, and $814 \mathrm{~cm}$. Therefore, it can be concluded that moderate current velocities dominated during this time interval.

Based on the available data, it can be concluded that the entire section is a monotonous sequence of terrigenous sediments. The uppermost $3 \mathrm{~m}$ of the section is dominated by green, olive-grey, and greenish-grey sediments. From 3 to $9.1 \mathrm{~m}$, the sediment is mostly dark olive-grey and grades to dark grey below this level to $15.7 \mathrm{~m}$. The sandy interval contains black sandy turbidites (1594-1574 cm) with abundant mica and gravel clasts within the basal layers, as well as a minor debrite layer consisting of coarse grey detrital sand (1675$1674 \mathrm{~cm}$ ) with abundant bivalve shell fragments. This sandy interval is underlain by finer grained dark grey and dark olive-grey sediments.
This monotonous sequence contains sporadic small (up to $1 \mathrm{~cm}$ ) rock fragments and calcitic bivalve debris (Fig. 2). At certain levels (5 and $935 \mathrm{~cm}$ ), elevated diatom contents were observed in the sediments. The layer at $829 \mathrm{~cm}$ contains a small lens of light grey volcanic ash, less than $1 \mathrm{~cm}$ thick. As was previously noted, this monotonous section is only disturbed by the sandy interval $(1675-1570 \mathrm{~cm})$ containing a single layer of sandy turbidites and laminae of sands, mictites, and sandy silts, up to $30 \mathrm{~cm}$ thick, probably representing grain-flow deposits or debrites. The same silts occur above and below this interval.

Minor bioturbation structures are common throughout the section; horizontal lamination and normal graded bedding were observed in the sandy interval.

Based on the above data, the section was subdivided into three lithostratigraphic subunits (from top to bottom): member $1(0-1570 \mathrm{~cm})$ comprising sub-members $1 \mathrm{a}(0-310 \mathrm{~cm}), 1 \mathrm{~b}(310-910 \mathrm{~cm})$, and $1 \mathrm{c}(910-$ $1570 \mathrm{~cm})$; member $2(1570-1675 \mathrm{~cm})$; and member 3 (1675-1815 cm, this was not penetrated completely) (Fig. 2).

Clay minerals. Since the cored section consists predominantly of silts, fine-grained non-clay detrital minerals become common in the clay fraction. These are mainly quartz, plagioclase, and hornblende grains.

Dioctahedral finely dispersed micaceous clay minerals $(\mathrm{d} 060=1.49-1.50 \AA)$ are the dominant mineral phases. The X-ray diffraction data proved most of these minerals to be illitic materials with $\mathrm{Al}$ and $\mathrm{Fe}$ cations in octahedral positions. More hydrated phases, such as hydromica with up to $10-15 \%$ expandable layers are less common. Moreover, the diffractograms of the glyc-

Fig. 2. Lithology and grain size composition of core SO201-2-101-KL. MS is magnetic susceptibility. Symbols: (1) mictite, (2) silt with sand, (3) sandy-clayey silt, (4) sandy silt, (5) clayey silt, (6) lithologic boundary, (7) gravel, (8) sand, (9) silt, (10) clay, (11) coarse IRD, (12) bivalve shells and detritus, (13) diatoms, and (14) volcanic ash. B is bioturbation, and T is turbidites. 
erolated samples often show a weak reflection typical of minerals containing up to $25-30 \%$ smectite layers. These seem to be mixed-layer illite-smectite formed by the intense supergene alteration of micaceous minerals. It should be noted that the number of samples containing such mixed-layer minerals is greater in the lower part of the column.

Chlorite is another important component of the clay material. The X-ray diffraction data show that the chlorite is trioctahedral ferromagnesian and well crystallized in most samples. The first-order chlorite reflection at 13.8-13.9 A usually increases in intensity after calcining.

The fine clay fraction incorporates so-called expandable clay minerals, including smectites and mixed-layer smectite-illite with the predominance of smectite interlayers. Their joint consideration is reasonable, because the glycerol-saturated samples of these minerals exhibit a similar first-order reflection at 17-18 $\AA$, and the proportions of different components in the mixed-layer materials are estimated from the 9-10 $\AA$ peaks [16]. The interlayer cations are mostly divalent $(\mathrm{Mg}>\mathrm{Ca})$, and only a few samples from the uppermost three meters of the section contain smectite layers with monovalent $\mathrm{Na}$. The great majority of the expandable components is attributed to disordered mixed-layer minerals with $70-90 \%$ smectite interlayers.

Table 3 shows the results of the semiquantitative analysis of clay minerals in the $<2 \mu \mathrm{m}$ size fraction. Four groups of clay minerals were identified: illites and hydromicas (called for brevity illites), chlorites, smectites and mixed-layer minerals (called for brevity smectites), and kaolinites.

Qualitative characterization of clay minerals identified in the cored section is given below. The basal portion of the section (from the base to approximately $1250 \mathrm{~cm}$ ) exhibits little variations in the clay minerals. The micaceous minerals are dominated by aluminous low-Fe illite (the intensity ratio of the second- and firstorder reflections, I002/I001, is $0.30-0.34$ ). Mixedlayer illite-smectite minerals with a ratio of $0.70-0.75$ : $0.25-0.30$ are also abundant. The expandable minerals (with dominant smectite interlayers) contain a series of labile structures with up to $70-100 \%$ smectite interlayers. The sand-rich interval $1550-1600 \mathrm{~cm}$ is characterized by a higher content of ferromagnesian chlorite and a lower content of mixed-layer minerals.

The overlying member $(1114-1234 \mathrm{~cm})$ of homogeneous grayish green clayey-silty sediments is characterized by the highest fraction of expandable minerals (up to $32-35 \%$ ), which are primarily mixed-layers with 70-90\% smectite interlayers.
Upsection (up to about $755 \mathrm{~cm}$ ), the samples exhibit layer-to-layer variations in the composition and proportions of phyllosilicates. An interval of abundant smectite structures is distinguished between 934 and $974 \mathrm{~cm}$, and the micaceous components contain a significant amount of hydromica.

The uppermost part of the section (above $755 \mathrm{~cm}$ ) exhibits a sharp increase in the amount of illites; they contain more iron (I 002/I $001=0.27-0.29)$, and the percentage of hydromica remains about constant throughout the interval. As was previously noted, smectites from the uppermost 3-m interval are characterized by the presence of interlayer Na cations.

We distinguished two major assemblages of clay minerals (minerals are in order of increasing content): (1) kaolinite-chlorite-smectite-illite and (2) kaolinite-smectite-chlorite-illite. In the first assemblage, the illite/smectite and chlorite/smectite ratios are lower than those in the second assemblage. Eight intervals were identified on the basis of clay mineral assemblages in the cored section. The intervals 455-675 and 1095$1355 \mathrm{~cm}$ are dominated by assemblage I; 34-275, 675755 , and $1355-1655 \mathrm{~cm}$ are dominated by assemblage II; and 275-455, 755-1095, and 1655-1815 $\mathrm{cm}$ are characterized by fine interlayering of both assemblages.

The distribution of clay minerals and variations in proportions of minerals and mineral assemblages from base to top in the cored section are shown in Fig. 4. In the eighth interval $(1815-1655 \mathrm{~cm})$, illite content decreases cyclically upward, while the proportions of the remaining minerals fluctuate around constant values. The seventh interval $(1655-1355 \mathrm{~cm})$ exhibits strong variations in the proportions of all clay minerals, and chlorite is generally more abundant than in the previous interval. The sixth interval $(1355-1095 \mathrm{~cm})$ is characterized by the high average smectite content. Illite is present in small amounts and shows an upward decrease. Chlorite and kaolinite are present in small but fairly constant amounts. In the fifth interval (1095$755 \mathrm{~cm}$ ), the contents of all clay minerals are almost constant, but smectite and chlorite appear in more variable proportions than in the overlying sediments. In the fourth interval $(755-675 \mathrm{~cm})$, illite content remains constant but slightly higher as compared to the fifth interval, whereas chlorite and kaolinite tend to decrease and smectite increases. In the third interval (675$455 \mathrm{~cm}$ ), the contents of all clay minerals are constant, and smectite is always abundant. Illite content decreases slightly upward with a distinct decrease in the illite/chlorite ratio. In the second interval (455$275 \mathrm{~cm}$ ), illite and chlorite contents are constant, with a decrease in smectite and increase in kaolinite contents. The first interval $(275-34 \mathrm{~cm})$ shows high illite (especially in the last three samples), chlorite, and kaolinite and low smectite contents. 
Besides the boundaries between the assemblages and fine interlayering intervals, additional boundaries can be distinguished on the basis of variations in the contents and ratios of different clay minerals. For example, boundaries were placed at $75,365,890,1175,1315$, 1425, 1540, and $1750 \mathrm{~cm}$ (Fig. 4).

As can be seen in Fig. 4, the distribution of the assemblages exhibits cyclic variations, making two complete cycles $(34-670 \mathrm{~cm}$ and $670-1350 \mathrm{~cm}$ ) and one incomplete cycle (from $1350 \mathrm{~cm}$ to the bottom of the hole). Each complete cycle shows the following succession (from bottom to top): kaolinite-chloritesmectite-illite assemblage, fine interlayering of both assemblages, and kaolinite-smectite-chlorite-illite assemblage.

A comparison of the distribution of lithostratigraphic units (members and sub-members) and clay mineral assemblages revealed that sub-member la corresponds mainly to the kaolinite-smectite-chloriteillite assemblage, in which the proportions of the major groups of clay minerals are fairly similar to their average values in the modern sediments of the Yukon Delta and Arctic continental margin of Alaska (which are also related to Yukon sediment supply [17]) (Table 4). The composition of clay minerals in the middle course of the Yukon River is different from that of the Yukon Delta in a sharp decrease in smectite and an increase in chlorite components [18]. Sub-member $1 \mathrm{~b}$ is dominated by the kaolinite-chlorite-smectite-illite assemblage, whereas sub-member $1 \mathrm{c}$ exhibits both the dominance of the assemblages and their fine interlayering. Submember 2 is dominantly kaolinite-smectite-chlorite-illite, and sub-member 3 shows interlayering of both assemblages.

The observed ratios between the minerals may reflect climatic and hydrodynamic conditions, as well as their sources. It is well known in the Arctic Ocean, e.g., on the continental margin of the Laptev Sea, that sediments of cold stadial periods have higher illite content, and those of warm periods have higher smectite content [19]. The same results were reported from the southeastern part of the Bering Sea [20]. The data in Table 3 and Fig. 4 show that the influence of climate on clay minerals in the cored section (based on the high illite and low smectite contents and elevated illite/chlorite ratio) becomes relatively clear in the three uppermost samples, i.e., at $34-76 \mathrm{~cm}$ (deglacial sediments, Table 1). The second interval with the elevated illite/chlorite ratio is found between 460 and $650 \mathrm{~cm}$. As previously noted, high illite content was observed in the upper $755 \mathrm{~cm}$ of the section.

There is abundant evidence on the effect of the settling velocity of sediment particle on the proportions of clay minerals [21]. Considering the above observations on the relations between bottom current velocity and clay fraction content, a strong hydrodynamic effect might be expected to influence the ratios of clay minerals and the content of the $<2-\mu \mathrm{m}$ size fraction; e.g., this fraction should correlate positively with smectite and negatively with illite. The correlation matrix (Table 5) indicates the presence or absence of correlations between the four groups of minerals and the content of the $<2-\mu \mathrm{m}$ size fraction. As can be seen, the only significant correlation is that for chlorite $(r=-0.318)$. Therefore, the hydrodynamic factor is not dominant.

Table 5 also shows that the clay minerals can be categorized into three groups based on the correlation coefficients. The first group is illite, which exhibits a negative correlation with, primarily, smectite and chlorite and no correlation with kaolinite; the second group is chlorite and kaolinite; and the third group is smectite, which has a strong negative correlation with all other clay minerals. Generally, none of the clay minerals shows any positive correlation with other minerals. These results can be explained by the wide development of Early Paleozoic greenstone facies metamorphic rocks in Central Alaska; they are dominated by quartzmuscovite-chlorite schists locally intercalated with mafic metavolcanic rocks [22]. Chlorite and mica hydration products are obviously derived from this source. The Arctic climatic conditions of Alaska, which seem to have persisted since the Late Miocene, could also be important factor of illite enrichment. Smectite could also be supplied by soil erosion and weathering of Late Cenozoic (6-0 Ma) mafic volcanics, which are abundant along the western Alaskan margin and on the Bering Sea shelf [23]. An additional contribution of volcanic material from Kamchatka and even from the Aleutian Arc to the Shirshov Ridge area has to be taken into account. The reliable recognition of sources requires special methods and is beyond the scope of this study. Kaolinite is most likely derived from the Carboniferous sedimentary rocks hosting coal deposits in the Yukon-Tanana Upland [24].

Our results suggest that there are at least two groups of clay minerals, the old Paleozoic and young Pleistocene. The first group includes hydromica, partly illite, chlorite, kaolinite, and part of smectite. They represent the composition of clay minerals from the Lower Paleozoic shales of Central Alaska, which were metamorphosed to the greenstone facies, as well as from other Paleozoic rocks of this area. The average contents of these minerals in the $<2-\mu \mathrm{m}$ size fraction from the Pleistocene rocks considered here is estimated as follows: $42-46 \%$ illite and hydromica, 20-25\% chlorite, $7-10 \%$ kaolinite, and, probably, up to $5 \%$ smectite. The young clay minerals are part of illites (averaging 10\%), mixed-layer minerals, and part of smectites (totaling about $13-15 \%)$. The young illites formed largely under 
Table 3. The content of clay minerals in the $<2-\mu \mathrm{m}$ size fraction ( $\%$ rel.), mineral ratios, and mineral assemblages

\begin{tabular}{|c|c|c|c|c|c|c|c|c|}
\hline Sample, $\mathrm{cm}$ & Illite & Chlorite & Smectite & Kaolinite & Illite/Chlorite & Illite/Smectite & Chlorite/Smectite & Assemblage \\
\hline $34-35$ & 58 & 24 & 9 & 9 & 2.4 & 6.4 & 2.7 & 2 \\
\hline $54-55$ & 61 & 21 & 10 & 8 & 2.9 & 6.1 & 2.1 & 2 \\
\hline $74-76$ & 63 & 17 & 10 & 10 & 3.7 & 6.3 & 1.7 & 2 \\
\hline 94-95 & 53 & 25 & 14 & 8 & 2.1 & 3.8 & 1.8 & 2 \\
\hline $114-115$ & 55 & 19 & 16 & 10 & 2.9 & 3.4 & 1.2 & 2 \\
\hline $134-135$ & 53 & 24 & 13 & 10 & 2.2 & 4.1 & 1.8 & 2 \\
\hline $154-155$ & 49 & 25 & 15 & 11 & 2 & 3.3 & 1.7 & 2 \\
\hline $174-175$ & 49 & 24 & 18 & 9 & 2 & 2.7 & 1.3 & 2 \\
\hline $214-215$ & 50 & 17 & 25 & 8 & 2.9 & 2 & 0.7 & 1 \\
\hline $234-235$ & 51 & 21 & 18 & 10 & 2.4 & 2.8 & 1.2 & 2 \\
\hline $254-255$ & 50 & 26 & 13 & 11 & 1.9 & 3.8 & 2 & 2 \\
\hline $274-275$ & 52 & 21 & 18 & 9 & 2.5 & 2.9 & 1.2 & 2 \\
\hline $294-295$ & 50 & 20 & 21 & 9 & 2.5 & 2.4 & 1 & 1 \\
\hline $314-315$ & 55 & 21 & 16 & 8 & 2.6 & 3.4 & 1.3 & 2 \\
\hline $354-355$ & 52 & 20 & 20 & 8 & 2.6 & 2.6 & 1 & 1 \\
\hline $374-375$ & 50 & 19 & 25 & 6 & 2.6 & 2 & 0.8 & 1 \\
\hline $394-395$ & 50 & 26 & 17 & 7 & 1.9 & 2.9 & 1.5 & 2 \\
\hline $414-415$ & 51 & 19 & 23 & 7 & 2.7 & 2.2 & 0.8 & 1 \\
\hline $434-435$ & 58 & 20 & 14 & 8 & 2.9 & 4.1 & 1.4 & 2 \\
\hline $454-455$ & 53 & 20 & 19 & 8 & 2.7 & 2.8 & 1.1 & 2 \\
\hline $474-475$ & 50 & 15 & 29 & 6 & 3.3 & 1.7 & 0.5 & 1 \\
\hline $494-495$ & 53 & 19 & 21 & 7 & 2.8 & 2.5 & 0.9 & 1 \\
\hline $514-515$ & 54 & 15 & 22 & 9 & 3.6 & 2.5 & 0.7 & 1 \\
\hline $534-535$ & 54 & 18 & 19 & 9 & 3 & 2.8 & 0.9 & 1 \\
\hline $554-555$ & 57 & 16 & 20 & 7 & 3.6 & 2.9 & 0.8 & 1 \\
\hline $574-575$ & 53 & 17 & 22 & 8 & 3.1 & 2.4 & 0.8 & 1 \\
\hline $594-595$ & 53 & 17 & 21 & 9 & 3.1 & 2.5 & 0.8 & 1 \\
\hline $614-615$ & 59 & 15 & 21 & 5 & 3.9 & 2.8 & 0.7 & 1 \\
\hline $634-635$ & 53 & 18 & 22 & 7 & 2.9 & 2.4 & 0.8 & 1 \\
\hline $654-655$ & 53 & 16 & 25 & 6 & 3.3 & 2.1 & 0.6 & 1 \\
\hline $674-675$ & 54 & 19 & 21 & 6 & 2.8 & 2.6 & 0.9 & 1 \\
\hline $694-695$ & 51 & 21 & 20 & 8 & 2.4 & 2.6 & 1.1 & 2 \\
\hline $714-715$ & 53 & 20 & 20 & 7 & 2.7 & 2.7 & 1 & 2 \\
\hline $734-735$ & 52 & 23 & 15 & 10 & 2.3 & 3.5 & 1.5 & 2 \\
\hline $754-755$ & 56 & 19 & 18 & 7 & 2.9 & 3.1 & 1.1 & 2 \\
\hline $774-775$ & 48 & 21 & 23 & 8 & 2.3 & 2.1 & 0.9 & 1 \\
\hline $794-795$ & 49 & 24 & 18 & 9 & 2 & 2.7 & 1.3 & 2 \\
\hline $814-815$ & 48 & 18 & 25 & 9 & 2.7 & 1.9 & 0.7 & 1 \\
\hline $841-842$ & 51 & 21 & 19 & 9 & 2.4 & 2.7 & 1.1 & 2 \\
\hline $854-855$ & 47 & 23 & 20 & 10 & 2 & 2.4 & 1.2 & 2 \\
\hline $874-875$ & 45 & 22 & 24 & 9 & 2 & 1.9 & 0.9 & 1 \\
\hline $894-895$ & 44 & 23 & 24 & 9 & 1.9 & 1.8 & 1 & 1 \\
\hline $921-922$ & 49 & 29 & 14 & 8 & 1.7 & 3.5 & 2.1 & 2 \\
\hline $934-935$ & 48 & 20 & 25 & 7 & 2.4 & 1.9 & 0.8 & 1 \\
\hline $954-955$ & 42 & 17 & 33 & 8 & 2.5 & 1.3 & 0.5 & 1 \\
\hline $974-975$ & 52 & 19 & 21 & 8 & 2.7 & 2.5 & 0.9 & 1 \\
\hline 994-995 & 45 & 28 & 19 & 8 & 1.6 & 2.4 & 1.5 & 2 \\
\hline
\end{tabular}


Table 3. (Contd.)

\begin{tabular}{|c|c|c|c|c|c|c|c|c|}
\hline Sample, cm & Illite & Chlorite & Smectite & Kaolinite & Illite/Chlorite & Illite/Smectite & Chlorite/Smectite & Assemblage \\
\hline $974-975$ & 52 & 19 & 21 & 8 & 2.7 & 2.5 & 0.9 & 1 \\
\hline 994-995 & 45 & 28 & 19 & 8 & 1.6 & 2.4 & 1.5 & 2 \\
\hline $1016-1017$ & 46 & 26 & 20 & 8 & 1.8 & 2.3 & 1.3 & 2 \\
\hline $1034-1035$ & 46 & 17 & 30 & 7 & 2.7 & 1.5 & 0.6 & 1 \\
\hline $1054-1055$ & 48 & 21 & 23 & 8 & 2.3 & 2.1 & 0.9 & 1 \\
\hline $1074-1075$ & 44 & 23 & 24 & 9 & 1.9 & 1.8 & 1 & 1 \\
\hline $1094-1095$ & 43 & 25 & 23 & 9 & 1.7 & 1.9 & 1.1 & 2 \\
\hline $1114-1115$ & 49 & 17 & 27 & 7 & 2.9 & 1.8 & 0.6 & 1 \\
\hline $1134-1135$ & 46 & 18 & 29 & 7 & 2.6 & 1.6 & 0.6 & 1 \\
\hline $1154-1155$ & 40 & 20 & 32 & 8 & 2 & 1.3 & 0.6 & 1 \\
\hline $1174-1175$ & 45 & 17 & 31 & 7 & 2.6 & 1.5 & 0.5 & 1 \\
\hline $1194-1195$ & 37 & 20 & 36 & 7 & 1.9 & 1 & 0.6 & 1 \\
\hline $1214-1215$ & 46 & 18 & 29 & 7 & 2.6 & 1.6 & 0.6 & 1 \\
\hline $1234-1235$ & 42 & 19 & 31 & 8 & 2.2 & 1.4 & 0.6 & 1 \\
\hline $1254-1255$ & 51 & 18 & 24 & 7 & 2.8 & 2.1 & 0.8 & 1 \\
\hline $1274-1275$ & 49 & 21 & 23 & 7 & 2.3 & 2.1 & 0.9 & 1 \\
\hline $1294-1295$ & 58 & 23 & 11 & 8 & 2.5 & 5.3 & 2.1 & 2 \\
\hline $1314-1315$ & 45 & 19 & 29 & 7 & 2.4 & 1.6 & 0.7 & 1 \\
\hline $1334-1335$ & 49 & 19 & 24 & 8 & 2.6 & 2 & 0.8 & 1 \\
\hline $1354-1355$ & 50 & 19 & 23 & 8 & 2.6 & 2.2 & 0.8 & 1 \\
\hline $1374-1375$ & 50 & 23 & 18 & 9 & 2.2 & 2.8 & 1.3 & 2 \\
\hline 1394-1395 & 45 & 26 & 20 & 9 & 1.7 & 2.3 & 1.3 & 2 \\
\hline $1414-1415$ & 53 & 21 & 17 & 9 & 2.5 & 3.1 & 1.2 & 2 \\
\hline $1434-1435$ & 43 & 24 & 23 & 10 & 1.8 & 1.9 & 1 & 2 \\
\hline $1454-1455$ & 43 & 26 & 22 & 9 & 1.7 & 2 & 1.2 & 2 \\
\hline $1474-1475$ & 48 & 25 & 20 & 7 & 1.9 & 2.4 & 1.3 & 2 \\
\hline $1494-1495$ & 47 & 23 & 20 & 10 & 2 & 2.4 & 1.2 & 2 \\
\hline $1514-1515$ & 47 & 23 & 23 & 7 & 2 & 2 & 1 & 2 \\
\hline $1534-1535$ & 48 & 23 & 21 & 8 & 2.1 & 2.3 & 1.1 & 2 \\
\hline $1554-1555$ & 43 & 30 & 21 & 6 & 1.4 & 2 & 1.4 & 2 \\
\hline $1574-1575$ & 47 & 28 & 18 & 7 & 1.7 & 2.6 & 1.6 & 2 \\
\hline $1594-1595$ & 49 & 25 & 19 & 7 & 2 & 2.6 & 1.3 & 2 \\
\hline $1614-1615$ & 43 & 22 & 27 & 8 & 2 & 1.6 & 0.8 & 1 \\
\hline $1634-1635$ & 46 & 25 & 21 & 8 & 1.8 & 2.2 & 1.2 & 2 \\
\hline $1654-1655$ & 46 & 25 & 22 & 7 & 1.8 & 2.1 & 1.1 & 2 \\
\hline $1674-1675$ & 44 & 21 & 26 & 9 & 2.1 & 1.7 & 0.8 & 1 \\
\hline $1694-1695$ & 49 & 19 & 24 & 8 & 2.6 & 2 & 0.8 & 1 \\
\hline $1714-1715$ & 50 & 22 & 20 & 8 & 2.3 & 2.5 & 1.1 & 2 \\
\hline $1734-1735$ & 51 & 22 & 20 & 7 & 2.3 & 2.5 & 1.1 & 2 \\
\hline $1754-1755$ & 44 & 24 & 24 & 8 & 1.8 & 1.8 & 1 & 1 \\
\hline $1774-1775$ & 48 & 22 & 23 & 7 & 2.2 & 2.1 & 1 & 1 \\
\hline $1794-1795$ & 51 & 19 & 22 & 8 & 2.7 & 2.3 & 0.9 & 1 \\
\hline $1814-1815$ & 53 & 22 & 17 & 8 & 2.4 & 3.1 & 1.3 & 2 \\
\hline
\end{tabular}

Note: Assemblage 1 is kaolinite-chlorite-smectite-illite, and assemblage 2 is kaolinite-smectite-chlorite-illite. 


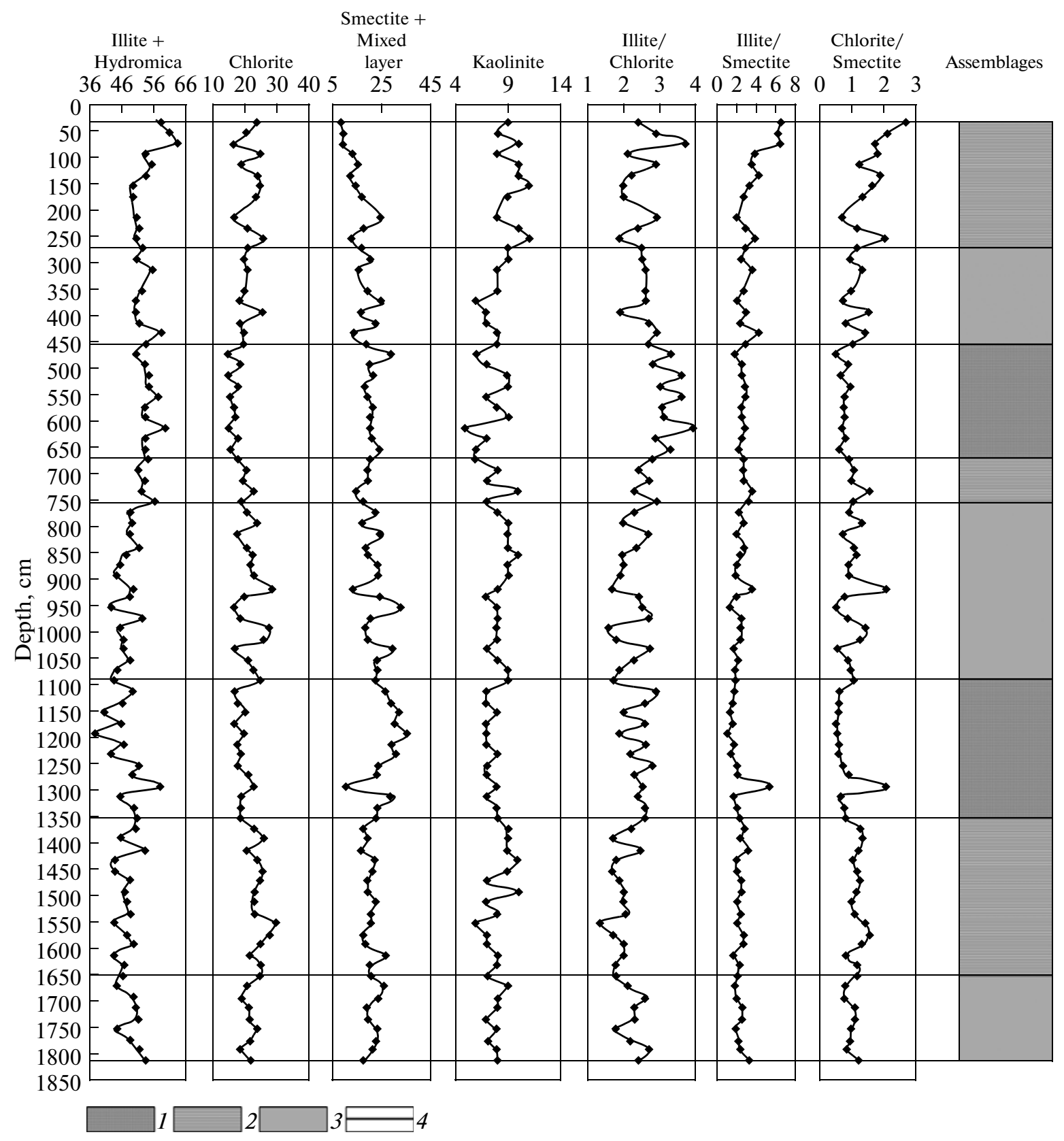

Fig. 4. Content of clay minerals (\% rel.) and the distribution of clay minerals ratios and assemblages in column SO201-2-101-KL. Symbols: (1) kaolinite- smectite-chlorite-illite assemblage, (2) kaolinite-chlorite-smectite-illite assemblage, (3) fine interlayering of two assemblages, and (4) boundaries between clay mineral assemblages.

the climatic conditions of cold periods, whereas the mixed-layer and young smectites formed in soils in continental setting through the alteration of volcanic material.

We applied R-mode factor analysis with varimax rotation to the standardized data to explore the distribution of clay minerals in the cored section. There are three factors fully accounting for the variance of four variables (groups of clay minerals). Factor 1 accounts for 46.924, factor 2 accounts for 35.346, and factor 3 explains 17.730 of the variance. Factor loadings are shown in Table 6. As can be seen, factor 1 reflects the mutual dilution of illite and smectite, i.e., the illite/smectite ratio. Factor 2 represents the mutual dilution of chlorite and smectite, with the dominance of chlorite, and factor 3 reflects the distribution of kaolinite. Based on factor 1 (Fig. 5), the cored section was divided into two nearly equal parts, the upper part $(0-$ 
Table 4. Composition of clay mineral assemblages (\% rel.) in the $<2-\mu \mathrm{m}$ size fraction from the Pleistocene sediments of the Shirshov Ridge (our data), Yukon Delta sediments [17], and surficial sediments from the northern continental margin of Alaska [17]

\begin{tabular}{l|c|c|c|c|c}
\hline \multicolumn{1}{c|}{ Location } & $\begin{array}{c}\text { Assemblage, num- } \\
\text { ber of samples }\end{array}$ & Illite (Ill) & Chlorite (Chl) & Smectite (Sm) & Kaolinite (K) \\
\hline Shirshov Ridge & $\begin{array}{c}\text { K-Chl-Sm-Ill } \\
(n=44) \\
\text { K-Sm-Chl-Ill } \\
(n=43)\end{array}$ & 49 & 19 & 25 & 7 \\
Shirshov Ridge & $n=87$ & 49 & 24 & 18 & 9 \\
Shirshov Ridge & $n=6$ & 41 & 26 & 21 & 8 \\
Yukon Delta & $n=10$ & 55 & 22 & 14 & 12 \\
$\begin{array}{l}\text { Northern Alaska continental } \\
\text { margin }\end{array}$ & & & & & 10 \\
\hline
\end{tabular}

Table 5. Correlation matrix for the clay mineral groups identified in the Shirshov Ridge sediments

\begin{tabular}{|c|c|c|c|c|c|c|c|c|}
\hline Component & 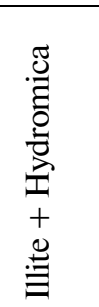 & $\frac{\stackrel{0}{0}}{\frac{0}{d}}$ & 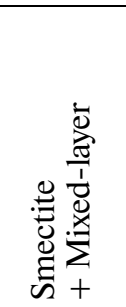 & 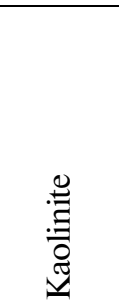 & 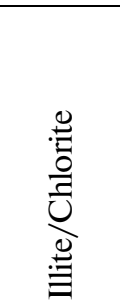 & 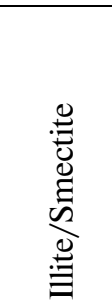 & 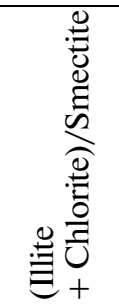 & 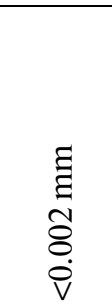 \\
\hline Illite + Hydromica & 1.000 & -0.324 & -0.702 & 0.004 & 0.696 & 0.780 & 0.683 & 0.096 \\
\hline Chlorite & & 1.000 & -0.414 & 0.271 & -0.880 & 0.161 & 0.328 & -0.318 \\
\hline Smectite + Mixed-layer & & & 1.000 & -0.408 & -0.010 & -0.888 & -0.911 & 0.130 \\
\hline Kaolinite & & & & 1.000 & -0.239 & 0.320 & 0.334 & -0.052 \\
\hline Illite/Chlorite & & & & & 1.000 & 0.226 & 0.058 & 0.263 \\
\hline Illite/Smectite & & & & & & 1.000 & 0.976 & -0.073 \\
\hline (Illite + Chlorite $) /$ Smectite & & & & & & & 1.000 & -0.125 \\
\hline$<0.002 \mathrm{~mm}$ & & & & & & & & 1.000 \\
\hline
\end{tabular}

$850 \mathrm{~cm}$ ) dominated by positive loadings and the lower part dominated by negative loadings. These results indicate the importance of illite for the upper part of the section and smectite for the lower part. The distribution of factor 2 revealed that, despite the overall dominance of chlorite (positive factor loadings), negative loadings clearly dominating within two intervals coincide with the occurrence of the kaolinite-chlorite-smectiteillite assemblage identified in this study. The distribution of factor 3 indicates an increasing supply of kaolinite at $0-285,750-910$, and $1390-1450 \mathrm{~cm}$. The sum of factors 1 and 2 clearly indicates the dominance of the sum of illite and chlorite in smectite dilution in the upper part of the section $(0-195 \mathrm{~cm})$. Below this depth (at 195-450, 700-1050, 1290-1815 cm), the section shows alternation of positive and negative loadings, and the importance of smectite is recognized at 450-700 and $1050-1290 \mathrm{~cm}$, especially in the lowermost interval.
An attempt was made to find out whether the distinction between these two mineral assemblages influences the bulk composition of samples. The semiquantitative approach of Biscaye applied in this study assumes that the sum of clay minerals in the quantified fraction is $100 \%$. However, the fraction is known to contain X-ray amorphous and non-clay crystalline materials (quartz, feldspars, etc.). The difference in the contents of chlorite and smectite in the samples is about $6 \%$ rel. Since the $<2-\mu \mathrm{m}$ size fraction accounts for $25-$ $30 \mathrm{wt} \%$ of the samples (Table 2), it can be assumed that this difference in the bulk sample is about $1-2 \%$, or even two times lower if the real fraction composition is taken into account. It should be noted that the two clay mineral assemblages are not very different in composition, especially compared with the differences between quartz and feldspars. This suggests that the above differences between the assemblages have no significant influence on the bulk sample composition. 

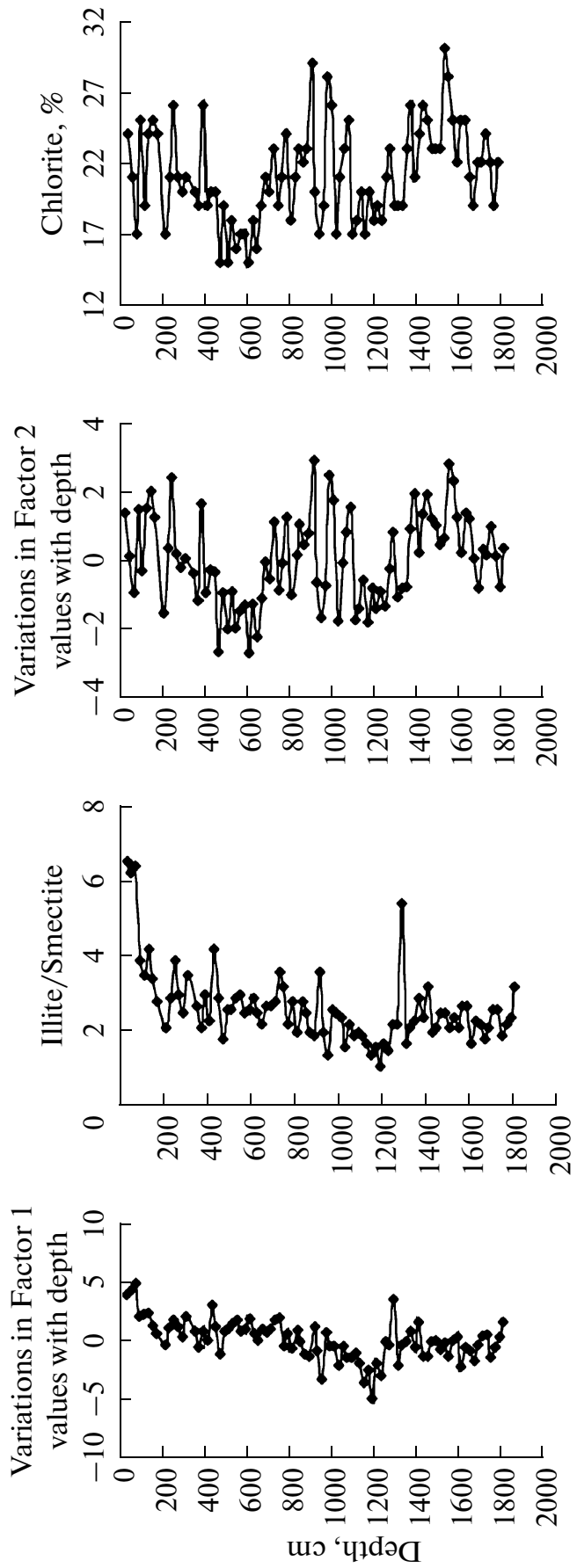
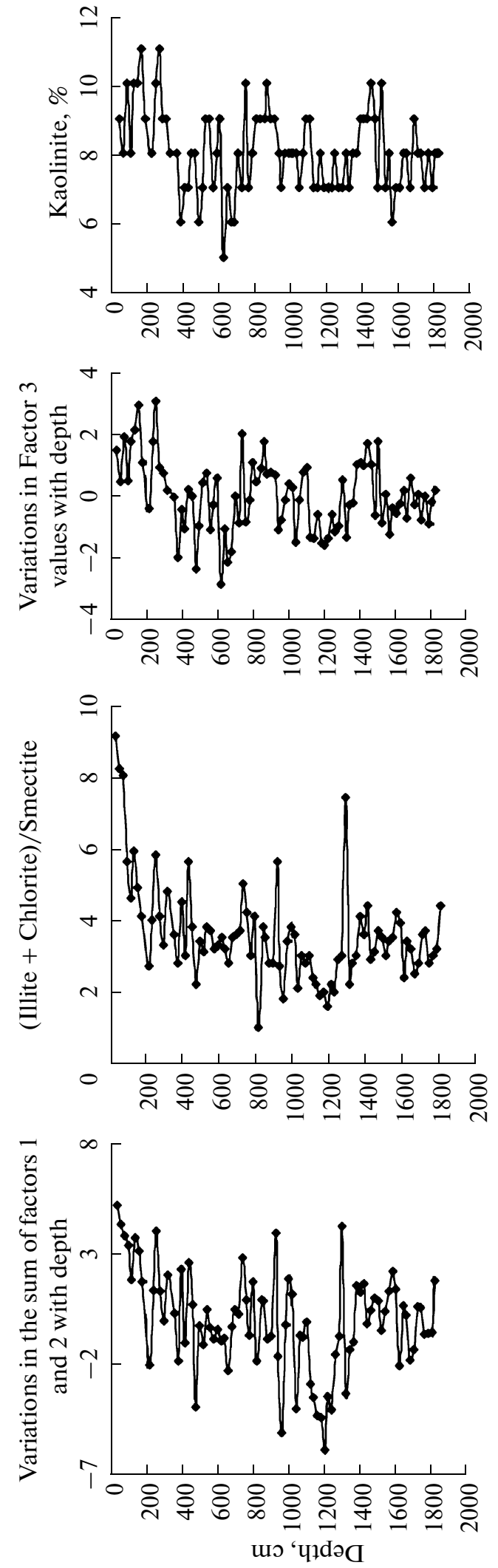
Sediment geochemistry. Table 7 shows XRF data for the bottom sediments, which are consistent with the observed monotonous lithology of the sedimentary section (except for member 2). Minor variations in the content of the $>0.063-\mathrm{mm}$ fraction (up to $16 \%$ ) do not influence the chemical composition of bulk sediments (Table 8), which is also supported by the average concentrations of the elements in sample groups with different sand content when calculated to a silica-free basis (Table 9).

The analytical results and data in Fig. 6 allow us to conclude that the sedimentary material in the samples (except for samples from the sandy interval) was most likely derived from the shales of Paleozoic fold belts [25]. The only appropriate source rocks in the islands and continental blocks around the Bering Sea are those of Alaska [26]. It is likely that the eroded material from Alaska was transported by the Yukon River draining the Brooks and Alaska ranges, as well as the Yukon-Tanana Upland. The latter seems to be the most likely provenance; its Paleozoic rocks are mostly carbonate-free phyllites, schists, and gneisses intruded by granites [24]. The upper reaches of several right tributaries of the Yukon River drain the Brooks Range, whose Paleozoic section (and that of the Alaska Range) is dominated by dolomites [27], which are found to be absent in our samples.

The slightly lower contents of $\mathrm{Al}_{2} \mathrm{O}_{3}, \mathrm{TiO}_{2}, \mathrm{Fe}_{2} \mathrm{O}_{3}^{*}$, $\mathrm{K}_{2} \mathrm{O}$, and $\mathrm{P}_{2} \mathrm{O}_{5}$ in our samples relative to the Paleozoic shales (Table 8 ) can be explained by the aforementioned wash-out of the finest clay fraction from Shirshov Ridge sediments, and the lower $\mathrm{MnO}$ reflects anaerobic diagenetic conditions and periodic deposition in the oxygen minimum zone, which will be discussed below. The younger fine-grained marine sediments have higher loss on ignition values than the Paleozoic shales, which underwent diagenetic, catagenetic, and early metamorphic alteration and partial loss of volatile components. As was mentioned above, the high $\mathrm{Na}_{2} \mathrm{O}$ values are due to sea salt contamination of the samples. It is also obvious that the composition of modern sediments of the Bering Sea shelf is distinctly different from that of our samples (Table 8), because the shelf area is dominated by marine blanket sands [1].

Figure 6 shows that the average composition of members 1 and 3 (cluster 1 ) is characterized by a higher value of hydrolysate module and a lower value of iron module relative to the average shale composition of Paleozoic fold belts (source rocks). Note that the hydrolysate module $(\mathrm{HM})$ is $\left(\mathrm{Al}_{2} \mathrm{O}_{3}+\mathrm{TiO}_{2}+\mathrm{Fe}_{2} \mathrm{O}_{3}+\right.$ $\mathrm{FeO}+\mathrm{MnO}) / \mathrm{SiO}_{2}$, and the iron module (IM) is $\left(\mathrm{Fe}_{2} \mathrm{O}_{3}+\mathrm{FeO}+\mathrm{MnO}\right) /\left(\mathrm{TiO}_{2}+\mathrm{Al}_{2} \mathrm{O}_{3}\right)$. The first value reflects lower $\mathrm{Al}$ and $\mathrm{K}$ contents in the sediments, and the second value indicates the deposition of dissolved

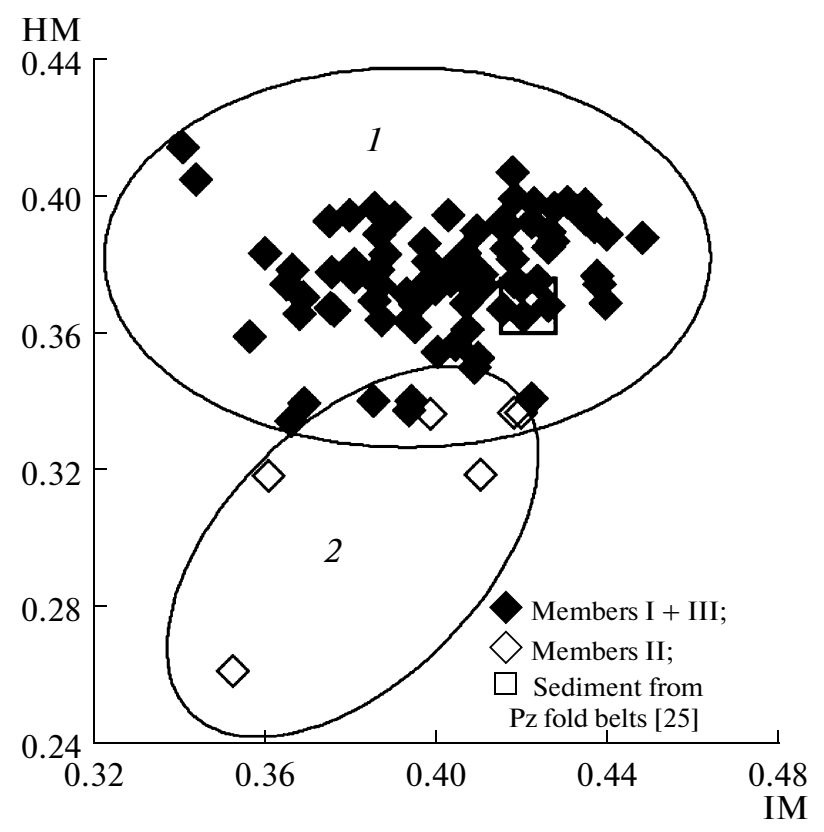

Fig. 6. Relationship between the values of hydrolysate and iron modules [47] in the sediments. 1 and 2 are clusters. See text for explanation.

Fe in the sediments in the river water-seawater mixing zone. This is a well-known phenomenon, which was described, for instance, in our previous study in the Yenisei Gulf of the Kara Sea [28].

The chemical composition of member 2 sediments differs markedly from that of the enclosing rocks, suggesting a proximal source area within the Shirshov Ridge on the basis on sedimentological considerations. The geology of the ridge is poorly understood, but available data [2] indicate that it consists of Triassic, Cretaceous, and Paleocene radiolarites, Lower-Upper Cretaceous amphibolitic gabbros, and Lower OligocenePleistocene shallow-water terrigenous sediments.

For the better understanding of the geochemical features of the sediments, Table 10 presents a Pearson correlation matrix of geochemical and grain-size components. The analysis of these data revealed several major groups of element associations. The first association comprises $\mathrm{SiO}_{2}, \mathrm{Sr}, \mathrm{Zr}, \mathrm{Ni}$, and sand; i.e., it is controlled by the mineral components of the sand fraction. The second association is $\mathrm{Al}_{2} \mathrm{O}_{3}, \mathrm{Ti}, \mathrm{Fe}, \mathrm{Mn}, \mathrm{K}, \mathrm{Mg}, \mathrm{P}, \mathrm{V}$, $\mathrm{Co}, \mathrm{Cu}, \mathrm{Zn}, \mathrm{Rb}, \mathrm{Y}, \mathrm{Nb}, \mathrm{Ba}, \mathrm{Pb}, \mathrm{LOI}, \mathrm{MnO}$, and silt. This is indicative of a mixture of the fine-grained clastic, silt and, in part, clay material with organic matter, and $\mathrm{Fe}$ and Mn oxyhydroxides (with the trace elements, both adsorbed onto the surface and incorporated into their mineral lattices). The third association comprises $\mathrm{CaO}, \mathrm{Sr}$, and sand and corresponds to the components of the sand fraction such as foraminiferal and mollusk shells, with isomorphic substitution of $\mathrm{Sr}$ for $\mathrm{Ca}$. The 
Table 6. The distribution of factor loadings for clay minerals

\begin{tabular}{|c|c|c|c|c|}
\hline Sample no., $\mathrm{cm}$ & Factor 1 & Factor 2 & Factor 3 & Factor $1+$ Factor 2 \\
\hline 34 & 3.83713 & 1.38016 & 1.50113 & 5.21729 \\
\hline 54 & 4.22948 & 0.113844 & 0.461861 & 4.343324 \\
\hline 74 & 4.80074 & -0.95765 & 1.936 & 3.843086 \\
\hline 94 & 1.9131 & 1.47626 & 0.486766 & 3.38936 \\
\hline 114 & 2.16489 & -0.34268 & 1.76771 & 1.822209 \\
\hline 134 & 2.23685 & 1.4891 & 2.15979 & 3.72595 \\
\hline 154 & 1.14046 & 1.99605 & 2.96135 & 3.13651 \\
\hline 174 & 0.521494 & 1.22835 & 1.09406 & 1.749844 \\
\hline 214 & -0.48209 & -1.5604 & -0.42116 & -2.04249 \\
\hline 234 & 0.982453 & 0.34595 & 1.78124 & 1.328403 \\
\hline 254 & 1.67062 & 2.38602 & 3.10309 & 4.05664 \\
\hline 274 & 1.12326 & 0.165209 & 0.941035 & 1.288469 \\
\hline 294 & 0.202471 & -0.23483 & 0.755057 & -0.03236 \\
\hline 314 & 2.00492 & 0.016966 & 0.191108 & 2.021886 \\
\hline 354 & 0.703599 & -0.39623 & -0.03956 & 0.307374 \\
\hline 374 & -0.65824 & -1.19581 & -1.99704 & -1.85405 \\
\hline 394 & 0.67536 & 1.62156 & -0.43489 & 2.29692 \\
\hline 414 & -0.0784 & -0.97638 & -1.06566 & -1.05479 \\
\hline 434 & 2.89988 & -0.29069 & 0.232451 & 2.609193 \\
\hline 454 & 1.07402 & -0.37998 & 0.005579 & 0.694044 \\
\hline 474 & -1.26079 & -2.70183 & -2.38505 & -3.96262 \\
\hline 494 & 0.696797 & -0.9544 & -0.97691 & -0.2576 \\
\hline 514 & 0.887528 & -2.03905 & 0.452544 & -1.15152 \\
\hline 534 & 1.39704 & -0.92717 & 0.740986 & 0.469871 \\
\hline 554 & 1.67101 & -2.00191 & -1.08488 & -0.3309 \\
\hline 574 & 0.645345 & -1.51661 & -0.28646 & -0.87127 \\
\hline 594 & 0.897191 & -1.32642 & 0.597899 & -0.42923 \\
\hline 614 & 1.78076 & -2.7334 & -2.86135 & -0.95264 \\
\hline 634 & 0.488568 & -1.31328 & -1.07134 & -0.82471 \\
\hline 654 & -0.05243 & -2.26018 & -2.15025 & -2.31261 \\
\hline 674 & 0.845687 & -1.13762 & -1.81747 & -0.29193 \\
\hline 694 & 0.547466 & -0.05546 & 0.009467 & 0.492011 \\
\hline 714 & 0.85855 & -0.5813 & -0.8804 & 0.277253 \\
\hline 734 & 1.70669 & 1.09913 & 2.01805 & 2.80582 \\
\hline 754 & 1.81413 & -0.90751 & -0.84175 & 0.906622 \\
\hline 774 & -0.59816 & -0.09369 & -0.12443 & -0.69185 \\
\hline 794 & 0.497246 & 1.23577 & 1.09513 & 1.733016 \\
\hline 814 & -0.82955 & -1.02343 & 0.470323 & -1.85298 \\
\hline 841 & 0.762939 & 0.145866 & 0.895445 & 0.908805 \\
\hline 854 & -0.15351 & 1.02035 & 1.79271 & 0.86684 \\
\hline 874 & -1.29583 & 0.420854 & 0.72102 & -0.87498 \\
\hline 894 & -1.5045 & 0.777707 & 0.772386 & -0.72679 \\
\hline 921 & 1.06427 & 2.908 & 0.692861 & 3.97227 \\
\hline 934 & -0.98549 & -0.66502 & -1.10646 & -1.65051 \\
\hline 954 & -3.44751 & -1.68978 & -0.7822 & -5.13729 \\
\hline
\end{tabular}


Table 6. (Contd.)

\begin{tabular}{|c|c|c|c|c|}
\hline Sample no., $\mathrm{cm}$ & Factor 1 & Factor 2 & Factor 3 & Factor $1+$ Factor 2 \\
\hline 974 & 0.58226 & -0.7817 & -0.13787 & -0.19944 \\
\hline 994 & -0.58322 & 2.47114 & 0.415972 & 1.887916 \\
\hline 1016 & -0.55853 & 1.74799 & 0.269088 & 1.189457 \\
\hline 1034 & -2.23787 & -1.80878 & -1.48509 & -4.04665 \\
\hline 1054 & -0.61028 & -0.08998 & -0.12389 & -0.70026 \\
\hline 1074 & -1.55704 & 0.79379 & 0.774724 & -0.76325 \\
\hline 1094 & -1.60598 & 1.52437 & 0.922688 & -0.08161 \\
\hline 1114 & -1.15892 & -1.75014 & -1.34823 & -2.90906 \\
\hline 1134 & -2.0842 & -1.43321 & -1.38823 & -3.51741 \\
\hline 1154 & -3.73947 & -0.59184 & -0.58134 & -4.33131 \\
\hline 1174 & -2.60425 & -1.82627 & -1.53041 & -4.43052 \\
\hline 1194 & -5.07228 & -0.84005 & -1.60246 & -5.91233 \\
\hline 1214 & -2.03772 & -1.44744 & -1.39029 & -3.48516 \\
\hline 1234 & -3.15634 & -0.93368 & -0.58774 & -4.09002 \\
\hline 1254 & -0.21187 & -1.35815 & -1.16342 & -1.57002 \\
\hline 1274 & -0.46948 & -0.27072 & -0.96409 & -0.7402 \\
\hline 1294 & 3.44778 & 0.809446 & 0.519184 & 4.257226 \\
\hline 1314 & -2.25245 & -1.08873 & -1.33866 & -3.34118 \\
\hline 1334 & -0.53305 & -0.82921 & -0.27311 & -1.36227 \\
\hline 1354 & -0.20102 & -0.80121 & -0.22626 & -1.00223 \\
\hline 1374 & 0.68571 & 0.885101 & 1.04467 & 1.570811 \\
\hline 1394 & -0.67105 & 1.92007 & 1.10804 & 1.24902 \\
\hline 1414 & 1.46944 & 0.188881 & 0.987255 & 1.658321 \\
\hline 1434 & -1.50781 & 1.33897 & 1.71018 & -0.16884 \\
\hline 1454 & -1.44827 & 1.89871 & 1.01937 & 0.45044 \\
\hline 1474 & -0.19895 & 1.2073 & -0.62294 & 1.008348 \\
\hline 1494 & -0.13734 & 1.01541 & 1.79199 & 0.878066 \\
\hline 1514 & -0.90905 & 0.449794 & -0.86037 & -0.45925 \\
\hline 1534 & -0.25849 & 0.64757 & 0.06787 & 0.389083 \\
\hline 1554 & -1.48607 & 2.79891 & -1.25082 & 1.31284 \\
\hline 1574 & -0.09826 & 2.31469 & -0.37793 & 2.216428 \\
\hline 1594 & 0.157328 & 1.22788 & -0.57717 & 1.385208 \\
\hline 1614 & -2.30469 & 0.203117 & -0.2529 & -2.10157 \\
\hline 1634 & -0.72433 & 1.37612 & 0.172761 & 0.651792 \\
\hline 1654 & -0.97617 & 1.18594 & -0.7116 & 0.209766 \\
\hline 1674 & -1.88257 & 0.048203 & 0.5818 & -1.83437 \\
\hline 1694 & -0.53912 & -0.82736 & -0.27284 & -1.36647 \\
\hline 1714 & 0.312525 & 0.30944 & 0.062003 & 0.621965 \\
\hline 1734 & 0.421 & 0.138596 & -0.77677 & 0.559596 \\
\hline 1754 & -1.60066 & 0.962479 & -0.0152 & -0.63818 \\
\hline 1774 & -0.72058 & 0.099126 & -0.91084 & -0.62146 \\
\hline 1794 & 0.213857 & -0.79857 & -0.1831 & -0.58471 \\
\hline 1814 & 1.45209 & 0.349528 & 0.196165 & 1.801618 \\
\hline
\end{tabular}


Table 7. Chemical composition of bottom sediments from the Shirshov Ridge, wt $\%$

\begin{tabular}{|c|c|c|c|c|c|c|c|c|c|}
\hline No., $\mathrm{cm}$ & LOI & $\mathrm{SiO}_{2}$ & $\mathrm{Al}_{2} \mathrm{O}_{3}$ & $\mathrm{TiO}_{2}$ & $\mathrm{Fe}_{2} \mathrm{O}_{3}$ & $\mathrm{MnO}$ & $\mathrm{K}_{2} \mathrm{O}$ & $\mathrm{CaO}$ & $\mathrm{MgO}$ \\
\hline 0 & 9.74 & 58.15 & 14.82 & 0.63 & 5.74 & 0.05 & 2.29 & 1.79 & 2.8 \\
\hline 16 & 9.92 & 55.72 & 14.93 & 0.65 & 5.95 & 0.053 & 2.41 & 3.56 & 2.91 \\
\hline 34 & 10.74 & 56.12 & 14.86 & 0.61 & 6.07 & 0.051 & 2.21 & 1.88 & 2.72 \\
\hline 54 & 9.87 & 56.88 & 16.39 & 0.7 & 5.81 & 0.042 & 2.73 & 1.71 & 2.64 \\
\hline 74 & 9.59 & 56.47 & 16.69 & 0.71 & 5.86 & 0.045 & 2.74 & 1.79 & 2.62 \\
\hline 94 & 7.53 & 58.66 & 15.79 & 0.7 & 5.86 & 0.053 & 2.47 & 2.5 & 2.71 \\
\hline 114 & 7.1 & 58.66 & 15.41 & 0.69 & 6.05 & 0.06 & 2.31 & 2.94 & 2.72 \\
\hline 134 & 7.5 & 58.13 & 15.59 & 0.71 & 6.48 & 0.061 & 2.41 & 2.32 & 2.91 \\
\hline 154 & 7.65 & 57.98 & 15.67 & 0.71 & 6.31 & 0.059 & 2.38 & 2.38 & 2.91 \\
\hline 174 & 7.52 & 58.26 & 15.89 & 0.71 & 6.14 & 0.06 & 2.39 & 2.19 & 2.87 \\
\hline 214 & 7.48 & 58.88 & 15.51 & 0.7 & 6.21 & 0.055 & 2.42 & 1.91 & 2.76 \\
\hline 234 & 6.91 & 59.77 & 15.43 & 0.7 & 5.87 & 0.054 & 2.34 & 2.09 & 2.66 \\
\hline 254 & 7.22 & 59.28 & 15.52 & 0.72 & 6.02 & 0.054 & 2.34 & 2.02 & 2.62 \\
\hline 274 & 7.74 & 58.71 & 15.25 & 0.74 & 6.1 & 0.054 & 2.41 & 2.06 & 2.84 \\
\hline 294 & 7.48 & 59.39 & 15.26 & 0.71 & 6.1 & 0.052 & 2.37 & 1.92 & 2.56 \\
\hline 314 & 7.38 & 59.45 & 14.76 & 0.7 & 6.01 & 0.053 & 2.40 & 2.04 & 2.65 \\
\hline 354 & 8.08 & 58.33 & 15.08 & 0.72 & 6.5 & 0.055 & 2.48 & 1.85 & 2.78 \\
\hline 374 & 8.41 & 58.46 & 14.83 & 0.7 & 6.13 & 0.056 & 2.57 & 1.85 & 2.73 \\
\hline 394 & 8.11 & 59.36 & 14.89 & 0.74 & 6.1 & 0.051 & 2.51 & 1.62 & 2.7 \\
\hline 414 & 8.11 & 58.85 & 15.19 & 0.73 & 6.38 & 0.052 & 2.47 & 1.62 & 2.78 \\
\hline 434 & 7.97 & 59.49 & 14.84 & 0.72 & 5.95 & 0.052 & 2.39 & 2.09 & 2.63 \\
\hline 454 & 6.48 & 61.39 & 14.47 & 0.71 & 5.53 & 0.05 & 2.33 & 2.46 & 2.52 \\
\hline 474 & 8.22 & 59.01 & 15.07 & 0.72 & 6.22 & 0.049 & 2.50 & 1.73 & 2.62 \\
\hline 494 & 8.03 & 59.71 & 15.18 & 0.73 & 5.78 & 0.05 & 2.57 & 1.74 & 2.59 \\
\hline 514 & 8.15 & 59.64 & 14.73 & 0.69 & 6.02 & 0.048 & 2.45 & 1.92 & 2.55 \\
\hline 534 & 8.69 & 59.63 & 14.07 & 0.69 & 5.97 & 0.046 & 2.38 & 2.26 & 2.41 \\
\hline 554 & 8.39 & 60.21 & 13.86 & 0.67 & 5.65 & 0.048 & 2.29 & 2.67 & 2.39 \\
\hline 574 & 8.6 & 58.94 & 14.39 & 0.69 & 6.07 & 0.05 & 2.39 & 2.18 & 2.6 \\
\hline 594 & 7.81 & 59.62 & 15.14 & 0.72 & 6.04 & 0.05 & 2.51 & 1.6 & 2.6 \\
\hline 614 & 8.38 & 59.06 & 14.99 & 0.72 & 6.1 & 0.051 & 2.49 & 1.77 & 2.65 \\
\hline 634 & 7.67 & 59.82 & 15.09 & 0.73 & 6.18 & 0.052 & 2.54 & 1.62 & 2.66 \\
\hline 654 & 8.71 & 58.73 & 14.77 & 0.72 & 6.4 & 0.055 & 2.46 & 1.85 & 2.71 \\
\hline 674 & 8.99 & 58.39 & 14.62 & 0.7 & 6.35 & 0.058 & 2.39 & 2.03 & 2.82 \\
\hline 694 & 8.15 & 58.2 & 15.21 & 0.71 & 6.84 & 0.059 & 2.45 & 1.83 & 3.02 \\
\hline 714 & 7.48 & 59.02 & 15.22 & 0.69 & 6.34 & 0.06 & 2.49 & 2.22 & 2.98 \\
\hline 734 & 8.61 & 59.05 & 14.96 & 0.63 & 5.48 & 0.052 & 2.48 & 1.76 & 2.73 \\
\hline 754 & 7.62 & 59.41 & 15.55 & 0.69 & 5.85 & 0.054 & 2.56 & 1.72 & 2.76 \\
\hline 774 & 8.2 & 58.65 & 15.48 & 0.7 & 6.55 & 0.052 & 2.55 & 1.63 & 2.71 \\
\hline 794 & 9.55 & 56.84 & 15.53 & 0.69 & 6.17 & 0.059 & 2.50 & 2.03 & 2.72 \\
\hline 814 & 7.16 & 60.27 & 14.86 & 0.72 & 6.4 & 0.053 & 2.47 & 1.72 & 2.69 \\
\hline 841 & 7.51 & 59.13 & 15.15 & 0.73 & 6.41 & 0.057 & 2.37 & 1.91 & 2.84 \\
\hline 854 & 7.35 & 59.12 & 15.14 & 0.73 & 6.55 & 0.06 & 2.28 & 1.93 & 2.81 \\
\hline 874 & 7.5 & 58.58 & 15.38 & 0.74 & 6.72 & 0.066 & 2.36 & 2.05 & 2.98 \\
\hline 894 & 7.85 & 57.86 & 15.51 & 0.74 & 6.71 & 0.066 & 2.33 & 2.02 & 2.98 \\
\hline 921 & 8.95 & 57.19 & 15.09 & 0.72 & 6.79 & 0.063 & 2.32 & 1.86 & 2.97 \\
\hline 934 & 9.11 & 58.87 & 14.97 & 0.71 & 5.81 & 0.052 & 2.37 & 1.71 & 2.56 \\
\hline 954 & 8.5 & 58.9 & 15.29 & 0.73 & 6.02 & 0.055 & 2.39 & 1.67 & 2.59 \\
\hline 974 & 9.74 & 57.13 & 15.11 & 0.7 & 6.49 & 0.057 & 2.42 & 1.69 & 2.77 \\
\hline
\end{tabular}


Table 7. (Contd.)

\begin{tabular}{|c|c|c|c|c|c|c|c|c|}
\hline No., $\mathrm{cm}$ & $\mathrm{Na}_{2} \mathrm{O}$ & $\mathrm{P}_{2} \mathrm{O}_{5}$ & $\mathrm{Cr}$ & $\mathrm{S}$ & V & Co & $\mathrm{Ni}$ & $\mathrm{Cu}$ \\
\hline 0 & 3.27 & 0.156 & 0.012 & 0.74 & 0.0195 & 0.0019 & 0.005 & 0.0031 \\
\hline 16 & 2.87 & 0.161 & 0.009 & 0.41 & 0.0164 & 0.0022 & 0.0045 & 0.0029 \\
\hline 34 & 3.32 & 0.145 & 0.010 & 0.86 & 0.0189 & 0.0013 & 0.0053 & 0.003 \\
\hline 54 & 2.36 & 0.177 & 0.011 & 0.32 & 0.0214 & 0.0013 & 0.0046 & 0.0023 \\
\hline 74 & 2.83 & 0.174 & 0.011 & 0.17 & 0.0266 & 0.0014 & 0.0043 & 0.0026 \\
\hline 94 & 3.07 & 0.156 & 0.009 & 0.16 & 0.0172 & 0.0018 & 0.0038 & 0.0022 \\
\hline 114 & 3.33 & 0.151 & 0.010 & 0.20 & 0.0172 & 0.0018 & 0.0041 & 0.0029 \\
\hline 134 & 3.25 & 0.148 & 0.009 & 0.23 & 0.0178 & 0.0017 & 0.0046 & 0.0031 \\
\hline 154 & 3.40 & 0.149 & 0.009 & 0.23 & 0.0172 & 0.0018 & 0.0042 & 0.0026 \\
\hline 174 & 3.31 & 0.15 & 0.010 & 0.19 & 0.0172 & 0.0014 & 0.0044 & 0.0027 \\
\hline 214 & 3.37 & 0.146 & 0.009 & 0.31 & 0.0186 & 0.0012 & 0.0041 & 0.0024 \\
\hline 234 & 3.55 & 0.143 & 0.008 & 0.20 & 0.0186 & 0.0019 & 0.0035 & 0.0021 \\
\hline 254 & 3.38 & 0.143 & 0.009 & 0.34 & 0.0172 & 0.0014 & 0.0038 & 0.0024 \\
\hline 274 & 3.27 & 0.146 & 0.008 & 0.27 & 0.0171 & 0.0014 & 0.0035 & 0.0022 \\
\hline 294 & 3.37 & 0.142 & 0.008 & 0.34 & 0.0176 & 0.0012 & 0.0037 & 0.0022 \\
\hline 314 & 3.69 & 0.145 & 0.008 & 0.41 & 0.0155 & 0.001 & 0.0039 & 0.0023 \\
\hline 354 & 3.47 & 0.143 & 0.010 & 0.28 & 0.018 & 0.001 & 0.0039 & 0.0029 \\
\hline 374 & 3.41 & 0.141 & 0.008 & 0.34 & 0.0167 & 0.0017 & 0.0037 & 0.0027 \\
\hline 394 & 3.05 & 0.151 & 0.009 & 0.34 & 0.0177 & 0.001 & 0.0038 & 0.0023 \\
\hline 414 & 3.04 & 0.146 & 0.009 & 0.34 & 0.0165 & 0.0011 & 0.0039 & 0.0024 \\
\hline 434 & 3.09 & 0.147 & 0.009 & 0.36 & 0.0178 & 0.0013 & 0.0038 & 0.0022 \\
\hline 454 & 3.27 & 0.146 & 0.009 & 0.29 & 0.0151 & 0.0013 & 0.0032 & 0.0018 \\
\hline 474 & 2.98 & 0.148 & 0.010 & 0.38 & 0.0184 & 0.0016 & 0.0045 & 0.0021 \\
\hline 494 & 3.03 & 0.146 & 0.009 & 0.14 & 0.0168 & 0.0016 & 0.0034 & 0.0019 \\
\hline 514 & 2.92 & 0.145 & 0.009 & 0.46 & 0.0137 & 0.0012 & 0.0039 & 0.002 \\
\hline 534 & 2.93 & 0.137 & 0.009 & 0.49 & 0.0156 & 0.0015 & 0.0037 & 0.0022 \\
\hline 554 & 2.95 & 0.141 & 0.009 & 0.41 & 0.0149 & 0.0009 & 0.0036 & 0.0018 \\
\hline 574 & 3.06 & 0.146 & 0.009 & 0.49 & 0.0156 & 0.0013 & 0.0039 & 0.0019 \\
\hline 594 & 3.10 & 0.145 & 0.010 & 0.27 & 0.0175 & 0.0014 & 0.0043 & 0.0024 \\
\hline 614 & 2.94 & 0.144 & 0.009 & 0.28 & 0.0168 & 0.0011 & 0.0042 & 0.0028 \\
\hline 634 & 2.89 & 0.144 & 0.010 & 0.21 & 0.0187 & 0.0016 & 0.0042 & 0.0022 \\
\hline 654 & 2.80 & 0.144 & 0.009 & 0.28 & 0.0191 & 0.0017 & 0.0047 & 0.0025 \\
\hline 674 & 2.92 & 0.147 & 0.009 & 0.24 & 0.0172 & 0.0013 & 0.0044 & 0.0028 \\
\hline 694 & 2.84 & 0.151 & 0.010 & 0.26 & 0.0179 & 0.0018 & 0.0053 & 0.003 \\
\hline 714 & 2.83 & 0.159 & 0.012 & 0.20 & 0.0186 & 0.0019 & 0.0052 & 0.003 \\
\hline 734 & 3.49 & 0.152 & 0.009 & 0.25 & 0.0187 & 0.001 & 0.0037 & 0.0022 \\
\hline 754 & 3.15 & 0.156 & 0.015 & 0.13 & 0.0189 & 0.0014 & 0.0048 & 0.0025 \\
\hline 774 & 2.93 & 0.15 & 0.012 & 0.23 & 0.0197 & 0.001 & 0.0046 & 0.0033 \\
\hline 794 & 2.92 & 0.153 & 0.010 & 0.30 & 0.0228 & 0.0014 & 0.0043 & 0.0034 \\
\hline 814 & 2.91 & 0.155 & 0.009 & 0.23 & 0.0176 & 0.0016 & 0.004 & 0.0026 \\
\hline 841 & 3.01 & 0.153 & 0.010 & 0.25 & 0.0216 & 0.0016 & 0.004 & 0.0029 \\
\hline 854 & 3.10 & 0.153 & 0.011 & 0.35 & 0.0185 & 0.0017 & 0.0044 & 0.0028 \\
\hline 874 & 2.97 & 0.158 & 0.011 & 0.15 & 0.0209 & 0.0012 & 0.0048 & 0.0035 \\
\hline 894 & 3.13 & 0.155 & 0.009 & 0.21 & 0.0205 & 0.0028 & 0.0044 & 0.0034 \\
\hline 921 & 3.02 & 0.152 & 0.010 & 0.51 & 0.019 & 0.0015 & 0.0042 & 0.0036 \\
\hline 934 & 3.10 & 0.138 & 0.009 & 0.31 & 0.0171 & 0.0012 & 0.0037 & 0.0032 \\
\hline 954 & 3.18 & 0.141 & 0.010 & 0.23 & 0.0181 & 0.0014 & 0.0037 & 0.0031 \\
\hline 974 & 3.13 & 0.145 & 0.009 & 0.38 & 0.0194 & 0.001 & 0.0042 & 0.004 \\
\hline
\end{tabular}

GEOCHEMISTRY INTERNATIONAL Vol. $51 \quad$ No. 32013 
Table 7. (Contd.)

\begin{tabular}{|c|c|c|c|c|c|c|c|c|c|}
\hline No., cm & $\mathrm{Zn}$ & $\mathrm{Rb}$ & $\mathrm{Sr}$ & $\mathrm{Y}$ & $\mathrm{Zr}$ & $\mathrm{Nb}$ & $\mathrm{Ba}$ & As & $\mathrm{Pb}$ \\
\hline 0 & 0.0105 & 0.0086 & 0.0218 & 0.0024 & 0.0124 & 0.001 & 0.088 & 0.0022 & 0.0012 \\
\hline 16 & 0.0105 & 0.0084 & 0.0277 & 0.0026 & 0.0125 & 0.0009 & 0.097 & 0.0015 & 0.0016 \\
\hline 34 & 0.0106 & 0.0086 & 0.0196 & 0.0024 & 0.0121 & 0.0011 & 0.088 & 0.0023 & 0.0011 \\
\hline 54 & 0.0106 & 0.0112 & 0.0197 & 0.0027 & 0.0144 & 0.0016 & 0.089 & 0.0011 & 0.0022 \\
\hline 74 & 0.0108 & 0.011 & 0.0197 & 0.0025 & 0.0144 & 0.0018 & 0.093 & 0.0024 & 0.002 \\
\hline 94 & 0.0106 & 0.0088 & 0.0229 & 0.0028 & 0.015 & 0.0008 & 0.079 & 0.0009 & 0.0013 \\
\hline 114 & 0.0099 & 0.0075 & 0.0255 & 0.0025 & 0.0155 & 0.001 & 0.074 & 0.0016 & 0.0016 \\
\hline 134 & 0.0102 & 0.0088 & 0.0232 & 0.0027 & 0.0149 & 0.0012 & 0.078 & 0.0025 & 0.0016 \\
\hline 154 & 0.0105 & 0.0079 & 0.0229 & 0.0026 & 0.0142 & 0.0009 & 0.080 & 0.0022 & 0.0014 \\
\hline 174 & 0.0108 & 0.0082 & 0.0223 & 0.0027 & 0.0153 & 0.0012 & 0.075 & 0.0018 & 0.0012 \\
\hline 214 & 0.0102 & 0.0086 & 0.0228 & 0.0027 & 0.0152 & 0.0008 & 0.077 & 0.0018 & 0.0011 \\
\hline 234 & 0.0095 & 0.0087 & 0.0241 & 0.0028 & 0.0161 & 0.0008 & 0.071 & 0.0013 & 0.0018 \\
\hline 254 & 0.0099 & 0.0085 & 0.0232 & 0.0025 & 0.0153 & 0.001 & 0.073 & 0.0027 & 0.0018 \\
\hline 274 & 0.012 & 0.0089 & 0.0228 & 0.0026 & 0.0162 & 0.0011 & 0.071 & 0.0029 & 0.0016 \\
\hline 294 & 0.0098 & 0.0086 & 0.0224 & 0.0025 & 0.0159 & 0.0013 & 0.069 & 0.003 & 0.0012 \\
\hline 314 & 0.0094 & 0.0084 & 0.0247 & 0.0026 & 0.0165 & 0.0014 & 0.076 & 0.0029 & 0.0021 \\
\hline 354 & 0.0105 & 0.0092 & 0.0232 & 0.0027 & 0.0154 & 0.0014 & 0.070 & 0.0007 & 0.0012 \\
\hline 374 & 0.0102 & 0.0102 & 0.0215 & 0.0027 & 0.0158 & 0.0011 & 0.078 & 0.0015 & 0.0017 \\
\hline 394 & 0.0105 & 0.0104 & 0.021 & 0.0027 & 0.0167 & 0.0011 & 0.085 & 0.0024 & 0.0022 \\
\hline 414 & 0.0108 & 0.0102 & 0.0222 & 0.0027 & 0.016 & 0.0015 & 0.071 & 0.0017 & 0.0024 \\
\hline 434 & 0.0103 & 0.0098 & 0.0241 & 0.0027 & 0.0166 & 0.001 & 0.072 & 0.0027 & 0.0012 \\
\hline 454 & 0.0095 & 0.0091 & 0.0268 & 0.0025 & 0.0173 & 0.001 & 0.073 & 0.0015 & 0.0017 \\
\hline 474 & 0.0109 & 0.0099 & 0.0219 & 0.0028 & 0.0168 & 0.001 & 0.076 & 0.0026 & 0.0015 \\
\hline 494 & 0.0102 & 0.0105 & 0.0229 & 0.0028 & 0.0163 & 0.0015 & 0.076 & 0.0023 & 0.0018 \\
\hline 514 & 0.0104 & 0.01 & 0.022 & 0.0028 & 0.0156 & 0.0012 & 0.077 & 0.0023 & 0.002 \\
\hline 534 & 0.0099 & 0.0094 & 0.0214 & 0.0025 & 0.0156 & 0.0014 & 0.073 & 0.0018 & 0.0015 \\
\hline 554 & 0.0098 & 0.0087 & 0.0241 & 0.0027 & 0.0156 & 0.0008 & 0.073 & 0.0039 & 0.0016 \\
\hline 574 & 0.0101 & 0.0094 & 0.0228 & 0.0027 & 0.0155 & 0.0012 & 0.076 & 0.0023 & 0.0013 \\
\hline 594 & 0.0104 & 0.0098 & 0.0212 & 0.0027 & 0.0163 & 0.0015 & 0.077 & 0.002 & 0.0022 \\
\hline 614 & 0.0109 & 0.0094 & 0.0223 & 0.0029 & 0.0163 & 0.0012 & 0.080 & 0.0028 & 0.0012 \\
\hline 634 & 0.0103 & 0.0102 & 0.0213 & 0.0028 & 0.0158 & 0.0014 & 0.079 & 0.0026 & 0.0013 \\
\hline 654 & 0.011 & 0.0102 & 0.0205 & 0.0028 & 0.0148 & 0.0013 & 0.083 & 0.0017 & 0.0016 \\
\hline 674 & 0.0113 & 0.0091 & 0.0218 & 0.003 & 0.0138 & 0.0012 & 0.081 & 0.0018 & 0.0016 \\
\hline 694 & 0.0115 & 0.0095 & 0.0205 & 0.0028 & 0.0135 & 0.0009 & 0.085 & 0.0019 & 0.0024 \\
\hline 714 & 0.0113 & 0.0095 & 0.0242 & 0.0027 & 0.014 & 0.0014 & 0.095 & 0.0014 & 0.0015 \\
\hline 734 & 0.0099 & 0.0092 & 0.0223 & 0.0025 & 0.015 & 0.0006 & 0.090 & 0.002 & 0.0015 \\
\hline 754 & 0.0108 & 0.0096 & 0.022 & 0.0028 & 0.0163 & 0.0012 & 0.087 & 0.0019 & 0.0017 \\
\hline 774 & 0.0105 & 0.0092 & 0.0204 & 0.0027 & 0.0149 & 0.0014 & 0.070 & 0.0013 & 0.0017 \\
\hline 794 & 0.0112 & 0.0094 & 0.0209 & 0.0026 & 0.0138 & 0.001 & 0.074 & 0.0024 & 0.0018 \\
\hline 814 & 0.01 & 0.009 & 0.0222 & 0.0028 & 0.0158 & 0.0013 & 0.073 & 0.0017 & 0.0012 \\
\hline 841 & 0.0101 & 0.0087 & 0.0223 & 0.0029 & 0.0169 & 0.001 & 0.073 & 0.0008 & 0.0019 \\
\hline 854 & 0.0099 & 0.0077 & 0.022 & 0.0027 & 0.0159 & 0.0014 & 0.067 & 0.0018 & 0.0015 \\
\hline 874 & 0.0107 & 0.0088 & 0.0226 & 0.0028 & 0.0151 & 0.0014 & 0.072 & 0.0012 & 0.0014 \\
\hline 894 & 0.0105 & 0.0083 & 0.0226 & 0.003 & 0.0151 & 0.0011 & 0.072 & 0.0005 & 0.0013 \\
\hline 921 & 0.0109 & 0.0084 & 0.0205 & 0.0026 & 0.0141 & 0.0008 & 0.073 & 0.0025 & 0.0017 \\
\hline 934 & 0.0107 & 0.0085 & 0.0221 & 0.0027 & 0.0153 & 0.0012 & 0.073 & 0.0019 & 0.002 \\
\hline 954 & 0.0107 & 0.0087 & 0.0207 & 0.0028 & 0.0158 & 0.0013 & 0.072 & 0.0019 & 0.0018 \\
\hline 974 & 0.0112 & 0.0088 & 0.0207 & 0.0027 & 0.014 & 0.0012 & 0.073 & 0.0019 & 0.0013 \\
\hline
\end{tabular}


Table 7. (Contd.)

\begin{tabular}{|c|c|c|c|c|c|c|c|c|c|}
\hline No., $\mathrm{cm}$ & LOI & $\mathrm{SiO}_{2}$ & $\mathrm{Al}_{2} \mathrm{O}_{3}$ & $\mathrm{TiO}_{2}$ & $\mathrm{Fe}_{2} \mathrm{O}_{3}$ & $\mathrm{MnO}$ & $\mathrm{K}_{2} \mathrm{O}$ & $\mathrm{CaO}$ & $\mathrm{MgO}$ \\
\hline 994 & 8.99 & 57.36 & 15.21 & 0.72 & 6.78 & 0.058 & 2.42 & 1.7 & 2.77 \\
\hline 1016 & 9.17 & 56.79 & 15.04 & 0.69 & 6.64 & 0.062 & 2.20 & 1.82 & 3.15 \\
\hline 1034 & 9.15 & 58.93 & 14.38 & 0.71 & 6.27 & 0.053 & 2.26 & 1.71 & 2.56 \\
\hline 1054 & 9.36 & 59.81 & 13.96 & 0.69 & 5.57 & 0.052 & 2.16 & 1.9 & 2.4 \\
\hline 1074 & 8.53 & 60.43 & 13.99 & 0.71 & 5.72 & 0.053 & 2.21 & 1.75 & 2.44 \\
\hline 1094 & 8.7 & 60.38 & 14.05 & 0.68 & 5.32 & 0.052 & 2.17 & 2.08 & 2.34 \\
\hline 1114 & 7.81 & 59.36 & 15.15 & 0.73 & 6.32 & 0.054 & 2.44 & 1.74 & 2.73 \\
\hline 1134 & 8.2 & 58.97 & 14.78 & 0.72 & 6.49 & 0.053 & 2.42 & 1.76 & 2.64 \\
\hline 1154 & 6.66 & 59.74 & 14.81 & 0.8 & 6.74 & 0.07 & 2.38 & 1.91 & 3.06 \\
\hline 1174 & 6.47 & 60.15 & 14.59 & 0.77 & 6.66 & 0.069 & 2.34 & 1.96 & 2.95 \\
\hline 1194 & 6.7 & 60.62 & 14.57 & 0.77 & 6.12 & 0.063 & 2.30 & 1.94 & 2.8 \\
\hline 1214 & 6.5 & 61.39 & 13.95 & 0.72 & 6.11 & 0.065 & 2.31 & 1.99 & 2.34 \\
\hline 1234 & 6.94 & 59.74 & 15.35 & 0.78 & 6.5 & 0.051 & 2.62 & 1.55 & 2.72 \\
\hline 1254 & 7.15 & 59.18 & 15.32 & 0.77 & 6.47 & 0.052 & 2.51 & 1.67 & 2.74 \\
\hline 1274 & 9.33 & 57.78 & 14.66 & 0.68 & 6.01 & 0.057 & 2.51 & 2.56 & 2.53 \\
\hline 1294 & 8.01 & 59.16 & 15.62 & 0.72 & 5.91 & 0.054 & 2.63 & 1.147 & 2.63 \\
\hline 1314 & 6.32 & 60.67 & 15.1 & 0.75 & 6.37 & 0.057 & 2.51 & 1.89 & 2.68 \\
\hline 1334 & 6.58 & 60.25 & 15.31 & 0.76 & 6.4 & 0.059 & 2.54 & 1.77 & 2.78 \\
\hline 1354 & 6.87 & 59.44 & 15.25 & 0.76 & 6.96 & 0.058 & 2.58 & 1.61 & 2.95 \\
\hline 1374 & 6.43 & 59.82 & 15.44 & 0.79 & 7.01 & 0.061 & 2.61 & 1.7 & 2.87 \\
\hline 1394 & 6.55 & 59.86 & 15.36 & 0.76 & 6.79 & 0.059 & 2.58 & 1.69 & 2.87 \\
\hline 1414 & 8.36 & 57.56 & 15.34 & 0.72 & 6.71 & 0.059 & 2.52 & 1.66 & 3.15 \\
\hline 1434 & 6.16 & 60.06 & 15.47 & 0.77 & 6.85 & 0.067 & 2.47 & 1.95 & 2.99 \\
\hline 1454 & 9.2 & 55.72 & 15.27 & 0.69 & 6.58 & 0.064 & 2.31 & 1.86 & 3.2 \\
\hline 1474 & 7.31 & 58.97 & 15.31 & 0.76 & 6.76 & 0.069 & 2.35 & 1.83 & 2.99 \\
\hline 1494 & 6.93 & 59.26 & 15.07 & 0.76 & 7 & 0.07 & 2.33 & 1.88 & 2.99 \\
\hline 1514 & 8.55 & 57.66 & 15.15 & 0.72 & 6.51 & 0.066 & 2.24 & 1.81 & 3.07 \\
\hline 1534 & 9.46 & 57.01 & 14.81 & 0.68 & 6.08 & 0.062 & 2.17 & 1.91 & 3.09 \\
\hline 1554 & 8.75 & 57.99 & 14.74 & 0.7 & 6.19 & 0.065 & 2.12 & 1.82 & 3.11 \\
\hline 1574 & 3.92 & 68.23 & 12.43 & 0.56 & 4.51 & 0.05 & 2.02 & 2.22 & 1.84 \\
\hline 1594 & 4.92 & 64.05 & 14.24 & 0.69 & 5.31 & 0.054 & 2.27 & 2.01 & 2.38 \\
\hline 1614 & 5.27 & 63.33 & 14.41 & 0.77 & 5.97 & 0.059 & 2.36 & 1.93 & 2.64 \\
\hline 1634 & 6.64 & 61.01 & 13.72 & 0.73 & 5.96 & 0.06 & 2.38 & 2.3 & 2.96 \\
\hline 1654 & 5.31 & 63.04 & 13.47 & 0.72 & 5.74 & 0.063 & 2.31 & 2.7 & 2.76 \\
\hline 1674 & 5.76 & 61.8 & 13.88 & 0.73 & 6.05 & 0.062 & 2.29 & 2.21 & 2.92 \\
\hline 1694 & 7.53 & 59.94 & 14.43 & 0.7 & 5.98 & 0.055 & 2.56 & 1.86 & 2.86 \\
\hline 1714 & 7.61 & 59.19 & 14.86 & 0.78 & 6.35 & 0.053 & 2.64 & 2.05 & 2.77 \\
\hline 1734 & 6.78 & 60.61 & 14.8 & 0.79 & 6.57 & 0.052 & 2.68 & 1.59 & 2.75 \\
\hline 1754 & 6.9 & 60.22 & 14.84 & 0.79 & 6.77 & 0.055 & 2.62 & 1.72 & 2.7 \\
\hline 1774 & 7.6 & 59.21 & 15.05 & 0.74 & 6.41 & 0.051 & 2.65 & 1.65 & 2.83 \\
\hline 1794 & 10.74 & 55.16 & 15.06 & 0.67 & 5.9 & 0.049 & 2.56 & 1.88 & 2.98 \\
\hline 1814 & 6.94 & 60.94 & 14.49 & 0.71 & 6.15 & 0.057 & 2.41 & 1.66 & 2.58 \\
\hline
\end{tabular}


Table 7. (Contd.)

\begin{tabular}{|c|c|c|c|c|c|c|c|c|}
\hline No., cm & $\mathrm{Na}_{2} \mathrm{O}$ & $\mathrm{P}_{2} \mathrm{O}_{5}$ & $\mathrm{Cr}$ & $S$ & $\mathrm{~V}$ & $\mathrm{Co}$ & $\mathrm{Ni}$ & $\mathrm{Cu}$ \\
\hline 994 & 3.08 & 0.145 & 0.010 & 0.49 & 0.0184 & 0.0018 & 0.0045 & 0.0037 \\
\hline 1016 & 3.26 & 0.148 & 0.008 & 0.71 & 0.0181 & 0.0012 & 0.0038 & 0.0029 \\
\hline 1034 & 3.10 & 0.135 & 0.010 & 0.43 & 0.0154 & 0.0011 & 0.0045 & 0.0031 \\
\hline 1054 & 3.20 & 0.132 & 0.010 & 0.52 & 0.0165 & 0.0013 & 0.0037 & 0.0027 \\
\hline 1074 & 3.12 & 0.144 & 0.022 & 0.51 & 0.0165 & 0.0011 & 0.0057 & 0.0026 \\
\hline 1094 & 3.37 & 0.137 & 0.008 & 0.42 & 0.0141 & 0.0014 & 0.0035 & 0.0022 \\
\hline 1114 & 2.93 & 0.152 & 0.011 & 0.33 & 0.0186 & 0.0016 & 0.0045 & 0.0027 \\
\hline 1134 & 3.07 & 0.156 & 0.009 & 0.44 & 0.0179 & 0.0012 & 0.0045 & 0.0032 \\
\hline 1154 & 3.14 & 0.156 & 0.010 & 0.26 & 0.0205 & 0.0018 & 0.0046 & 0.0033 \\
\hline 1174 & 3.16 & 0.146 & 0.010 & 0.49 & 0.0208 & 0.0013 & 0.0049 & 0.0032 \\
\hline 1194 & 3.41 & 0.149 & 0.010 & 0.28 & 0.0159 & 0.0011 & 0.0039 & 0.003 \\
\hline 1214 & 3.59 & 0.143 & 0.006 & 0.50 & 0.0143 & 0.0011 & 0.0033 & 0.0033 \\
\hline 1234 & 2.96 & 0.149 & 0.009 & 0.24 & 0.0207 & 0.0016 & 0.0046 & 0.0032 \\
\hline 1254 & 3.29 & 0.152 & 0.010 & 0.27 & 0.0188 & 0.0014 & 0.0043 & 0.0026 \\
\hline 1274 & 2.93 & 0.151 & 0.009 & 0.43 & 0.0211 & 0.0012 & 0.0046 & 0.0031 \\
\hline 1294 & 2.88 & 0.158 & 0.009 & 0.42 & 0.0233 & 0.0015 & 0.0049 & 0.0032 \\
\hline 1314 & 2.89 & 0.159 & 0.009 & 0.22 & 0.0212 & 0.0011 & 0.0045 & 0.0036 \\
\hline 1334 & 2.81 & 0.161 & 0.009 & 0.20 & 0.0221 & 0.002 & 0.0042 & 0.0034 \\
\hline 1354 & 2.79 & 0.16 & 0.009 & 0.21 & 0.0209 & 0.0018 & 0.0051 & 0.0032 \\
\hline 1374 & 2.64 & 0.162 & 0.011 & 0.13 & 0.0228 & 0.0019 & 0.0049 & 0.0037 \\
\hline 1394 & 2.83 & 0.164 & 0.009 & 0.17 & 0.0182 & 0.0023 & 0.005 & 0.0035 \\
\hline 1414 & 3.10 & 0.164 & 0.013 & 0.38 & 0.0184 & 0.0019 & 0.0059 & 0.0035 \\
\hline 1434 & 2.66 & 0.168 & 0.010 & 0.12 & 0.0216 & 0.0022 & 0.0051 & 0.0051 \\
\hline 1454 & 4.08 & 0.144 & 0.009 & 0.64 & 0.0215 & 0.002 & 0.0049 & 0.0041 \\
\hline 1474 & 2.98 & 0.147 & 0.009 & 0.22 & 0.0217 & 0.0026 & 0.0049 & 0.0056 \\
\hline 1494 & 3.06 & 0.15 & 0.012 & 0.19 & 0.0202 & 0.0019 & 0.0054 & 0.0036 \\
\hline 1514 & 3.45 & 0.145 & 0.009 & 0.44 & 0.0169 & 0.002 & 0.0042 & 0.0031 \\
\hline 1534 & 3.75 & 0.137 & 0.009 & 0.57 & 0.0178 & 0.0014 & 0.0044 & 0.0032 \\
\hline 1554 & 3.66 & 0.132 & 0.009 & 0.40 & 0.0176 & 0.002 & 0.0042 & 0.0036 \\
\hline 1574 & 3.51 & 0.123 & 0.009 & 0.27 & 0.0115 & 0.0007 & 0.0055 & 0.0017 \\
\hline 1594 & 3.32 & 0.141 & 0.010 & 0.25 & 0.015 & 0.0028 & 0.0193 & 0.0029 \\
\hline 1614 & 2.68 & 0.144 & 0.010 & 0.14 & 0.0174 & 0.0019 & 0.0042 & 0.0021 \\
\hline 1634 & 3.42 & 0.15 & 0.029 & 0.34 & 0.0168 & 0.0018 & 0.0064 & 0.0024 \\
\hline 1654 & 3.14 & 0.15 & 0.010 & 0.33 & 0.0158 & 0.0017 & 0.0039 & 0.0023 \\
\hline 1674 & 3.18 & 0.153 & 0.009 & 0.52 & 0.0164 & 0.0014 & 0.004 & 0.0023 \\
\hline 1694 & 3.22 & 0.144 & 0.010 & 0.39 & 0.015 & 0.0018 & 0.0039 & 0.003 \\
\hline 1714 & 2.86 & 0.153 & 0.010 & 0.22 & 0.0185 & 0.0013 & 0.0048 & 0.0032 \\
\hline 1734 & 2.68 & 0.142 & 0.012 & 0.14 & 0.021 & 0.0011 & 0.0047 & 0.003 \\
\hline 1754 & 2.53 & 0.146 & 0.011 & 0.21 & 0.0191 & 0.0012 & 0.0042 & 0.0035 \\
\hline 1774 & 2.94 & 0.146 & 0.011 & 0.37 & 0.0186 & 0.0016 & 0.0043 & 0.0026 \\
\hline 1794 & 3.74 & 0.138 & 0.009 & 0.84 & 0.0157 & 0.0017 & 0.0041 & 0.0026 \\
\hline 1814 & 3,03 & 0,149 & 0,010 & 0,65 & 0,0155 & 0,0013 & 0,0042 & 0.0029 \\
\hline
\end{tabular}


Table 7. (Contd.)

\begin{tabular}{|c|c|c|c|c|c|c|c|c|c|}
\hline No., cm & $\mathrm{Zn}$ & $\mathrm{Rb}$ & $\mathrm{Sr}$ & $\mathrm{Y}$ & $\mathrm{Zr}$ & $\mathrm{Nb}$ & $\mathrm{Ba}$ & As & $\mathrm{Pb}$ \\
\hline 994 & 0.011 & 0.009 & 0.021 & 0.0027 & 0.0144 & 0.0011 & 0.079 & 0.0028 & 0.002 \\
\hline 1016 & 0.0092 & 0.0077 & 0.0224 & 0.0025 & 0.0148 & 0.001 & 0.061 & 0.0021 & 0.0015 \\
\hline 1034 & 0.0104 & 0.0086 & 0.0212 & 0.0025 & 0.0148 & 0.0013 & 0.074 & 0.0027 & 0.0016 \\
\hline 1054 & 0.0102 & 0.0076 & 0.0235 & 0.0027 & 0.0152 & 0.001 & 0.069 & 0.0021 & 0.001 \\
\hline 1074 & 0.01 & 0.0081 & 0.0235 & 0.0027 & 0.0167 & 0.0013 & 0.064 & 0.0018 & 0.0009 \\
\hline 1094 & 0.0096 & 0.008 & 0.0252 & 0.0027 & 0.0167 & 0.0007 & 0.071 & 0.0009 & 0.0014 \\
\hline 1114 & 0.0108 & 0.0092 & 0.0232 & 0.0028 & 0.0165 & 0.0012 & 0.077 & 0.0028 & 0.0015 \\
\hline 1134 & 0.0114 & 0.0093 & 0.0233 & 0.0029 & 0.0163 & 0.0012 & 0.087 & 0.0021 & 0.0016 \\
\hline 1154 & 0.011 & 0.0088 & 0.025 & 0.0026 & 0.0173 & 0.0013 & 0.073 & 0.0003 & 0.0011 \\
\hline 1174 & 0.011 & 0.0081 & 0.0254 & 0.0031 & 0.0178 & 0.0012 & 0.076 & 0.0031 & 0.0013 \\
\hline 1194 & 0.0105 & 0.0086 & 0.027 & 0.003 & 0.0178 & 0.0011 & 0.076 & 0.0046 & 0.0017 \\
\hline 1214 & 0.0094 & 0.0078 & 0.0252 & 0.003 & 0.0187 & 0.0009 & 0.079 & 0.0029 & 0.0011 \\
\hline 1234 & 0.0124 & 0.0104 & 0.0234 & 0.0031 & 0.0183 & 0.001 & 0.087 & 0.0034 & 0.0029 \\
\hline 1254 & 0.0111 & 0.0101 & 0.0231 & 0.0029 & 0.018 & 0.0014 & 0.087 & 0.0028 & 0.0019 \\
\hline 1274 & 0.012 & 0.0104 & 0.0218 & 0.003 & 0.0155 & 0.0012 & 0.095 & 0.0035 & 0.0012 \\
\hline 1294 & 0.0121 & 0.0112 & 0.0192 & 0.0028 & 0.016 & 0.0013 & 0.098 & 0.0029 & 0.0018 \\
\hline 1314 & 0.0114 & 0.0108 & 0.0249 & 0.003 & 0.0174 & 0.0016 & 0.096 & 0.0009 & 0.0018 \\
\hline 1334 & 0.0116 & 0.0108 & 0.0231 & 0.003 & 0.0173 & 0.0013 & 0.097 & 0.0026 & 0.0022 \\
\hline 1354 & 0.0118 & 0.0097 & 0.0209 & 0.0031 & 0.0163 & 0.001 & 0.094 & 0.0009 & 0.0015 \\
\hline 1374 & 0.0128 & 0.0109 & 0.0219 & 0.0031 & 0.0166 & 0.0012 & 0.096 & 0.0011 & 0.0019 \\
\hline 1394 & 0.0116 & 0.0105 & 0.0213 & 0.003 & 0.0176 & 0.0015 & 0.098 & 0.0027 & 0.0016 \\
\hline 1414 & 0.0114 & 0.01 & 0.0206 & 0.0027 & 0.0153 & 0.0011 & 0.090 & 0.0024 & 0.0016 \\
\hline 1434 & 0.0119 & 0.0089 & 0.0246 & 0.0031 & 0.0163 & 0.0013 & 0.089 & 0.0023 & 0.0017 \\
\hline 1454 & 0.0111 & 0.0092 & 0.0255 & 0.0027 & 0.015 & 0.0011 & 0.079 & 0.0032 & 0.0016 \\
\hline 1474 & 0.0116 & 0.0084 & 0.0213 & 0.0027 & 0.016 & 0.0011 & 0.081 & 0.0020 & 0.0019 \\
\hline 1494 & 0.0111 & 0.0089 & 0.0236 & 0.0028 & 0.0163 & 0.0013 & 0.072 & 0.0012 & 0.0018 \\
\hline 1514 & 0.0107 & 0.0082 & 0.0221 & 0.0027 & 0.0144 & 0.0011 & 0.069 & 0.0030 & 0.0010 \\
\hline 1534 & 0.0099 & 0.0083 & 0.0246 & 0.0027 & 0.0145 & 0.0009 & 0.073 & 0.0011 & 0.0015 \\
\hline 1554 & 0.01 & 0.0078 & 0.0224 & 0.0024 & 0.0145 & 0.0006 & 0.064 & 0.0030 & 0.0016 \\
\hline 1574 & 0.0073 & 0.0074 & 0.0322 & 0.0024 & 0.0195 & 0.0011 & 0.081 & 0.0036 & 0.0014 \\
\hline 1594 & 0.0087 & 0.0087 & 0.0291 & 0.0025 & 0.0179 & 0.0014 & 0.076 & 0.0021 & 0.0012 \\
\hline 1614 & 0.0098 & 0.009 & 0.0263 & 0.0031 & 0.0185 & 0.0009 & 0.068 & 0.0011 & 0.0023 \\
\hline 1634 & 0.0095 & 0.0081 & 0.0263 & 0.0028 & 0.0182 & 0.0011 & 0.072 & 0.0016 & 0.0022 \\
\hline 1654 & 0.0091 & 0.0083 & 0.0289 & 0.0027 & 0.0184 & 0.0012 & 0.071 & 0.0025 & 0.0012 \\
\hline 1674 & 0.0089 & 0.0084 & 0.0267 & 0.0029 & 0.0188 & 0.0011 & 0.067 & 0.0045 & 0.0013 \\
\hline 1694 & 0.0102 & 0.0104 & 0.0265 & 0.0028 & 0.017 & 0.0012 & 0.067 & 0.0021 & 0.0020 \\
\hline 1714 & 0.0117 & 0.0112 & 0.0228 & 0.003 & 0.0177 & 0.001 & 0.080 & 0.0023 & 0.0020 \\
\hline 1734 & 0.0115 & 0.0108 & 0.0234 & 0.0029 & 0.0182 & 0.0014 & 0.074 & 0.0029 & 0.0013 \\
\hline 1754 & 0.012 & 0.0104 & 0.023 & 0.003 & 0.0172 & 0.0009 & 0.074 & 0.0025 & 0.0018 \\
\hline 1774 & 0.0114 & 0.011 & 0.0225 & 0.0031 & 0.018 & 0.0014 & 0.080 & 0.0052 & 0.0016 \\
\hline 1794 & 0.0098 & 0.0101 & 0.0227 & 0.0028 & 0.0158 & 0.0013 & 0.073 & 0.0023 & 0.0023 \\
\hline 1814 & 0.0097 & 0.0096 & 0.0243 & 0.0028 & 0.0169 & 0.0009 & 0.082 & 0.0027 & 0.0012 \\
\hline
\end{tabular}


Table 8. Average chemical composition of bottom sediments, wt $\%$

\begin{tabular}{|c|c|c|c|c|c|c|c|c|c|c|c|c|}
\hline Sediment & $\begin{array}{l}>0.063- \\
\text { mm frac- } \\
\text { tion }\end{array}$ & $\mathrm{SiO}_{2}$ & $\mathrm{Al}_{2} \mathrm{O}_{3}$ & $\mathrm{TiO}_{2}$ & $\mathrm{Fe}_{2} \mathrm{O}_{3}$ & $\mathrm{MnO}$ & $\mathrm{K}_{2} \mathrm{O}$ & $\mathrm{CaO}$ & $\mathrm{MgO}$ & $\mathrm{Na}_{2} \mathrm{O}$ & $\mathrm{P}_{2} \mathrm{O}_{5}$ & LOI \\
\hline \multirow[t]{3}{*}{ Members $1+3$} & $\begin{array}{c}0-5 \\
(n=45)\end{array}$ & 58.61 & 15.13 & 0.72 & 6.32 & 0.06 & 2.45 & 1.84 & 2.76 & 3.05 & 0.15 & 8.27 \\
\hline & $\begin{array}{c}5-10 \\
(n=28)\end{array}$ & 59.26 & 14.93 & 0.72 & 6.22 & 0.06 & 2.41 & 1.96 & 2.76 & 3.15 & 0.15 & 7.72 \\
\hline & $\begin{array}{l}10-16 \\
(n=9)\end{array}$ & 59.55 & 14.95 & 0.72 & 6.18 & 0.06 & 2.38 & 2.01 & 2.77 & 3.34 & 0.15 & 7.24 \\
\hline $\begin{array}{l}\text { Members } 1+3 \text {, } \\
\text { mean }\end{array}$ & $(n=82)$ & 58.94 & 15.04 & 0.72 & 6.27 & 0.06 & 2.43 & 1.90 & 2.76 & 3.16 & 0.15 & 7.97 \\
\hline $\begin{array}{l}\text { Shale from } \mathrm{Pz} \\
\text { fold belts [25] }\end{array}$ & - & 59.46 & 17.53 & 0.74 & 6.56 & 0.14 & 3.04 & 1.82 & 2.38 & 1.52 & 0.13 & 6.04 \\
\hline $\begin{array}{l}\text { Modern bottom } \\
\text { sediments from } \\
\text { Bering Sea shelf } \\
{[44](n=123)}\end{array}$ & - & 72.31 & 11.06 & 0.63 & 3.73 & 0.06 & 1.57 & 2.83 & 1.72 & 3.07 & n.d. & n.d. \\
\hline Member 2 & $>16(n=6)$ & 63.64 & 13.82 & 0.70 & 5.52 & 0.06 & 2.26 & 2.26 & 2.51 & 3.18 & 0.14 & 5.28 \\
\hline
\end{tabular}

Note: n.d. — not determined.

Table 9. Average concentrations of elements in the Shirshov Ridge sediments with variable sand content (wt \%) recalculated to a silica-free basis

\begin{tabular}{c|c|c|c|c|c|c|c|c|c|c}
\hline Sand content & $\mathrm{Al}_{2} \mathrm{O}_{3}$ & $\mathrm{TiO}_{2}$ & $\mathrm{Fe}_{2} \mathrm{O}_{3}$ & $\mathrm{MnO}$ & $\mathrm{K}_{2} \mathrm{O}$ & $\mathrm{CaO}$ & $\mathrm{MgO}$ & $\mathrm{Na}_{2} \mathrm{O}$ & $\mathrm{P}_{2} \mathrm{O}_{5}$ & \multicolumn{2}{c}{ LOI } \\
\hline $0-5$ & 36.55 & 1.74 & 15.27 & 0.14 & 5.92 & 4.45 & 6.67 & 7.37 & 0.36 & 19.98 \\
$5-10$ & 36.64 & 1.77 & 15.27 & 0.15 & 5.92 & 4.81 & 6.77 & 7.73 & 0.368 & 18.95 \\
$10-16$ & 36.96 & 1.78 & 15.28 & 0.15 & 5.88 & 4.97 & 6.85 & 8.26 & 0.371 & 17.90 \\
$>16$ & 38.01 & 1.92 & 15.18 & 0.17 & 6.22 & 6.22 & 6.90 & 8.75 & 0.385 & 14.52 \\
\hline
\end{tabular}

fourth association is $\mathrm{Cr}, \mathrm{Ni}, \mathrm{S}, \mathrm{As}$, $\mathrm{LOI}$, and $\mathrm{Al}$ with clay and, in part, silt fractions. These occur in organic matter, clays, and pyrite.

$\mathrm{R}$-mode factor analysis with varimax rotation was used for the quantification of the role of different factors in the development of the geochemical associations (Table 11). Factors 1 to 4 together explain more than $75 \%$ of the variance. The percentage of variance accounted for by each factor are $35.742 \%$ for factor 1 (significant positive loadings for $\mathrm{Al}, \mathrm{K}, \mathrm{P}, \mathrm{V}, \mathrm{Zn}, \mathrm{Rb}$, and $\mathrm{Ba}), 17.236 \%$ for factor 2 ( $\mathrm{Ti}, \mathrm{Fe}, \mathrm{Mn}, \mathrm{Mg}$, and $\mathrm{Cu}$ ), $14.725 \%$ for factor $3(\mathrm{Si}, \mathrm{Sr}$, and $\mathrm{Zr}$ ), and $8.025 \%$ for factor $4(\mathrm{Ca}$ and $\mathrm{Co})$. The analysis of variations in the factors with depth showed that factors 1, 2, 3 and 4 are controlled by the abundance of silt, clay, sand, and bio- genic calcite, respectively (Fig. 7). Therefore, the compositional variations in the cored sediments are a function of grain-size fractionation.

In our opinion, the geochemical data in combination with micropaleontological and other indicators are particularly useful for the identification of sediments accumulated under conditions of high productivity and anoxia within the oxygen minimum zone. The $\mathrm{Ba} / \mathrm{Al}$ [29] and $\mathrm{Ca} / \mathrm{Al}$ ratios were used as productivity indicators. It should be noted that each of the methods used has its own shortcomings. For example, part of $\mathrm{Ba}$ in sand-rich sediments may be related to detrital feldspars. Sand-size bivalve fragments could be derived by slope processes and lateral transport. Therefore, data on the samples with low sand contents and showing compara- 
Table 10. Correlation matrix for geochemical and grain-size components from the Shirshov Ridge sediments using Pearson correlation coefficients

\begin{tabular}{|c|c|c|c|c|c|c|c|c|}
\hline Component & $\mathrm{SiO}_{2}$ & $\mathrm{Al}_{2} \mathrm{O}_{3}$ & $\mathrm{TiO}_{2}$ & $\overline{\mathrm{Fe}_{2} \mathrm{O}_{3}}$ & $\mathrm{MnO}$ & $\mathrm{K}_{2} \mathrm{O}$ & $\mathrm{CaO}$ & $\mathrm{MgO}$ \\
\hline $\mathrm{SiO}_{2}$ & 1.000 & -0.666 & 0.031 & -0.444 & -0.037 & -0.232 & 0.183 & -0.563 \\
\hline $\mathrm{Al}_{2} \mathrm{O}_{3}$ & & 1.000 & 0.279 & 0.462 & 0.005 & 0.551 & -0.294 & 0.453 \\
\hline $\mathrm{TiO}_{2}$ & & & 1.000 & 0.651 & 0.356 & 0.416 & -0.302 & 0.387 \\
\hline $\mathrm{Fe}_{2} \mathrm{O}_{3}$ & & & & 1.000 & 0.543 & 0.295 & -0.340 & 0.723 \\
\hline $\mathrm{MnO}$ & & & & & 1.000 & -0.345 & 0.134 & 0.633 \\
\hline $\mathrm{K}_{2} \mathrm{O}$ & & & & & & 1.000 & -0.384 & 0.120 \\
\hline $\mathrm{CaO}$ & & & & & & & 1.000 & -0.132 \\
\hline $\mathrm{MgO}$ & & & & & & & & 1.000 \\
\hline
\end{tabular}

Table 10. (Contd.)

\begin{tabular}{l|r|r|r|r|r|r|r|r|r|r}
\hline Component & $\mathrm{Na}_{2} \mathrm{O}$ & \multicolumn{1}{c|}{$\mathrm{P}_{2} \mathrm{O}_{5}$} & \multicolumn{1}{c|}{$\mathrm{Cr}$} & \multicolumn{1}{c|}{$\mathrm{S}$} & \multicolumn{1}{c|}{$\mathrm{V}$} & \multicolumn{1}{c|}{$\mathrm{Co}$} & \multicolumn{1}{c|}{$\mathrm{Ni}$} & \multicolumn{1}{c|}{$\mathrm{Cu}$} & \multicolumn{1}{c}{$\mathrm{Zn}$} & \multicolumn{1}{c}{$\mathrm{Rb}$} \\
\hline $\mathrm{Na}_{2} \mathrm{O}$ & 1.000 & -0.530 & -0.064 & 0.431 & -0.411 & -0.038 & -0.005 & -0.122 & -0.518 & -0.549 \\
$\mathrm{P}_{2} \mathrm{O}_{5}$ & & 1.000 & 0.129 & -0.362 & 0.648 & 0.244 & 0.018 & 0.266 & 0.487 & 0.438 \\
$\mathrm{Cr}$ & & & 1.000 & -0.053 & 0.049 & 0.055 & 0.233 & -0.008 & -0.014 & -0.050 \\
$\mathrm{~S}$ & & & & 1.000 & -0.298 & -0.223 & -0.079 & -0.062 & -0.282 & -0.216 \\
$\mathrm{~V}$ & & & & & 1.000 & 0.238 & -0.017 & 0.526 & 0.661 & 0.411 \\
$\mathrm{Co}$ & & & & & & 1.000 & 0.412 & 0.400 & 0.166 & -0.015 \\
$\mathrm{Ni}$ & & & & & & & 1.000 & 0.145 & -0.103 & -0.023 \\
$\mathrm{Cu}$ & & & & & & & & 1.000 & 0.543 & -0.003 \\
$\mathrm{Zn}$ & & & & & & & & & 1.000 & 0.564 \\
$\mathrm{Rb}$ & & & & & & & & & & 1.000 \\
\hline
\end{tabular}

Table 10. (Contd.)

\begin{tabular}{l|r|r|r|r|r|r|r|r|r|r|r}
\hline Component & $\mathrm{Sr}$ & $\mathrm{Y}$ & $\mathrm{Zr}$ & \multicolumn{1}{c|}{$\mathrm{Nb}$} & \multicolumn{1}{c|}{$\mathrm{Ba}$} & \multicolumn{1}{c|}{$\mathrm{As}$} & \multicolumn{1}{c}{$\mathrm{Pb}$} & \multicolumn{1}{c}{ LOI } & \multicolumn{1}{c}{ Sand } & \multicolumn{1}{c}{ Silt } & \multicolumn{1}{c}{ Clay } \\
\hline $\mathrm{Sr}$ & 1.000 & 0.001 & 0.638 & -0.160 & -0.262 & 0.147 & -0.160 & -0.679 & 0.740 & -0.664 & -0.414 \\
$\mathrm{Y}$ & & 1.000 & 0.431 & 0.089 & 0.329 & 0.060 & 0.200 & -0.294 & -0.226 & 0.234 & 0.075 \\
$\mathrm{Zr}$ & & & 1.000 & 0.077 & -0.018 & 0.261 & 0.092 & -0.763 & 0.501 & -0.360 & -0.427 \\
$\mathrm{Nb}$ & & & & 1.000 & 0.234 & -0.032 & 0.115 & -0.012 & -0.052 & 0.135 & -0.116 \\
$\mathrm{Ba}$ & & & & & 1.000 & 0.043 & 0.216 & -0.050 & -0.193 & 0.303 & -0.106 \\
$\mathrm{As}$ & & & & & & 1.000 & -0.025 & -0.062 & 0.136 & -0.050 & -0.196 \\
$\mathrm{~Pb}$ & & & & & & & 1.000 & 0.018 & -0.104 & 0.101 & 0.045 \\
$\mathrm{LOI}$ & & & & & & & & 1.000 & -0.624 & 0.498 & 0.449 \\
Sand & & & & & & & & & 1.000 & -0.873 & -0.597 \\
Silt & & & & & & & & & & 1.000 & 0.130 \\
Clay & & & & & & & & & & & 1.000 \\
\hline
\end{tabular}

ble results from both methods were found to be most reliable. The calculation revealed correspondence between high $\mathrm{Ba} / \mathrm{Al}$ and $\mathrm{Ca} / \mathrm{Al}$ ratios only at 16,1274 , and $1574 \mathrm{~cm}$. The most reliable data on anoxic conditions (V/Cr higher than 2.5) [29] were found at 74, 1294,1334 , and $1474 \mathrm{~cm}$.

Age of sediments and sedimentation rates. The analysis of data in Table 1 showed that Holocene sediments are missing in the cored section. The identified lithos- tratigraphic units are attributed to the following marine isotopic stages (from top to bottom): sub-member la to MIS 2-MIS 3a, sub-member $1 b$ to MIS 3-MIS 4, submember $1 \mathrm{c}$ to MIS 5a-d, member 2 to MIS 5e, and member 3 to MIS 6. It was found that sedimentation rates in sub-member 1a were highest during deglaciation and lowest during the Last Glacial Maximum and MIS 3a. In sub-member $1 b$, the interval 5-7 $\mathrm{m}$ with the highest sedimentation rates generally coincides with the 
Table 11. Factor loadings for major oxides and elements

\begin{tabular}{|c|c|c|c|c|}
\hline Component & Factor 1 & Factor 2 & Factor 3 & Factor 4 \\
\hline $\mathrm{SiO}_{2}$ & -0.06819 & -0.31711 & 0.842454 & 0.275716 \\
\hline $\mathrm{Al}_{2} \mathrm{O}_{3}$ & 0.513087 & 0.345267 & -0.57856 & -0.01034 \\
\hline $\mathrm{TiO}_{2}$ & 0.455857 & 0.639282 & 0.438591 & -0.09948 \\
\hline $\mathrm{Fe}_{2} \mathrm{O}_{3}$ & 0.271723 & 0.846487 & -0.10571 & -0.14548 \\
\hline $\mathrm{MnO}$ & -0.34492 & 0.816329 & 0.136247 & 0.257109 \\
\hline $\mathrm{K}_{2} \mathrm{O}$ & 0.906295 & 0.045018 & -0.06975 & -0.10311 \\
\hline $\mathrm{CaO}$ & -0.36449 & -0.21372 & -0.08326 & 0.549555 \\
\hline $\mathrm{MgO}$ & -0.02457 & 0.785638 & -0.31982 & 0.040134 \\
\hline $\mathrm{Na}_{2} \mathrm{O}$ & -0.72364 & -0.06326 & -0.06227 & -0.13195 \\
\hline $\mathrm{P}_{2} \mathrm{O}_{5}$ & 0.620359 & 0.281102 & -0.28415 & 0.402451 \\
\hline $\mathrm{Cr}$ & 0.042226 & 0.038163 & 0.102307 & 0.16357 \\
\hline S & -0.47869 & -0.13822 & -0.26743 & -0.36383 \\
\hline V & 0.54354 & 0.485106 & -0.30441 & 0.079586 \\
\hline $\mathrm{Co}$ & 0.008865 & 0.432956 & -0.099 & 0.482589 \\
\hline $\mathrm{Ni}$ & -0.01535 & -0.01358 & 0.123096 & 0.426854 \\
\hline $\mathrm{Cu}$ & 0.07149 & 0.742896 & -0.13648 & 0.113389 \\
\hline $\mathrm{Zn}$ & 0.643363 & 0.527713 & -0.19109 & -0.11951 \\
\hline $\mathrm{Rb}$ & 0.866747 & -0.05949 & 0.013845 & -0.19397 \\
\hline $\mathrm{Sr}$ & -0.43373 & -0.18552 & 0.578093 & 0.465109 \\
\hline $\mathrm{Y}$ & 0.478559 & 0.404892 & 0.442376 & -0.04819 \\
\hline $\mathrm{Zr}$ & 0.133207 & -0.03418 & 0.925301 & 0.013724 \\
\hline $\mathrm{Nb}$ & 0.46065 & -0.02785 & 0.046697 & -0.00727 \\
\hline $\mathrm{Ba}$ & 0.602194 & -0.01684 & -0.22391 & 0.310377 \\
\hline As & -0.05183 & -0.11861 & 0.224516 & -0.259 \\
\hline $\mathrm{Pb}$ & 0.406653 & 0.050037 & 0.029925 & -0.09681 \\
\hline
\end{tabular}




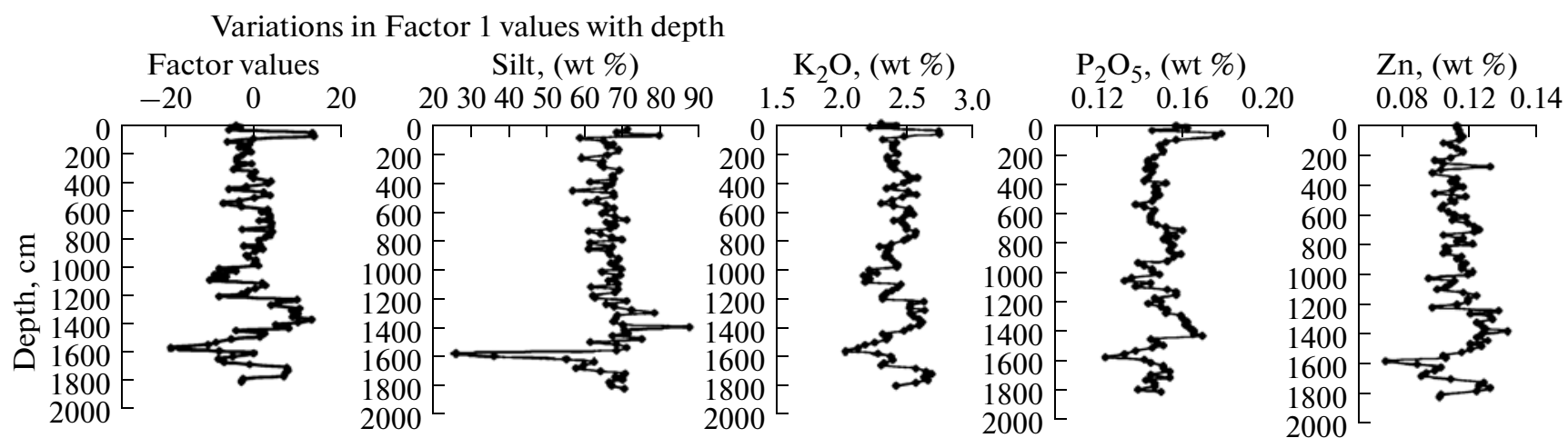

Variations in Factor 2 values with depth

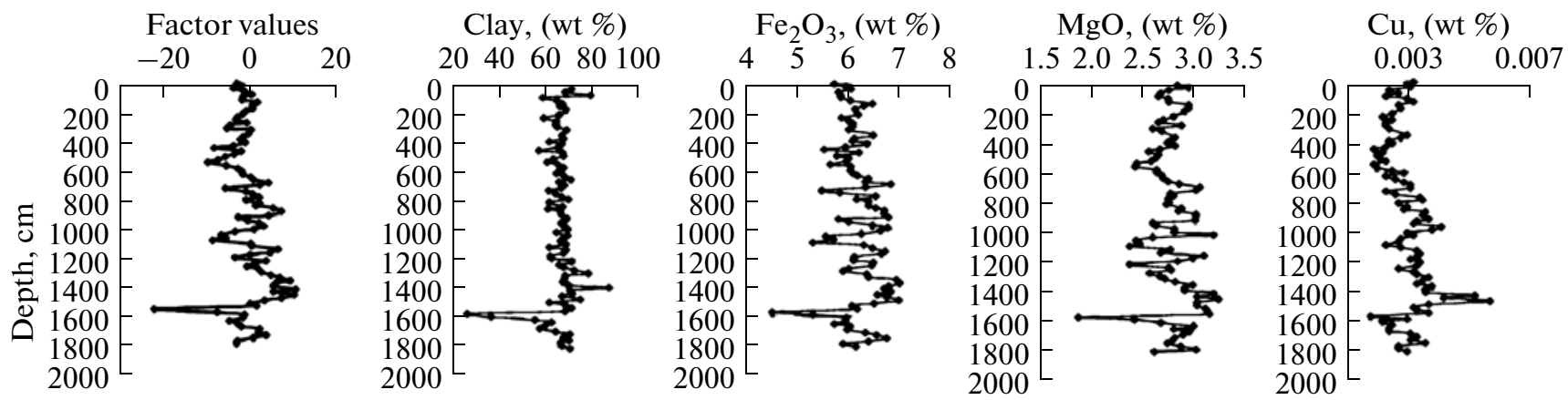

Variations in Factor 3 values with depth

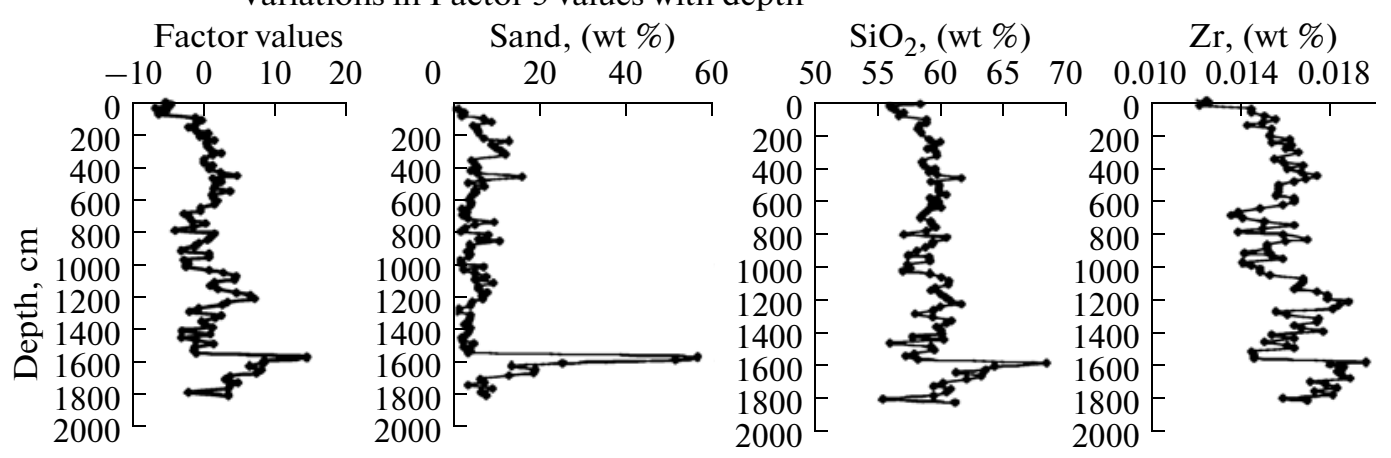

Variations in Factor 4 values with depth

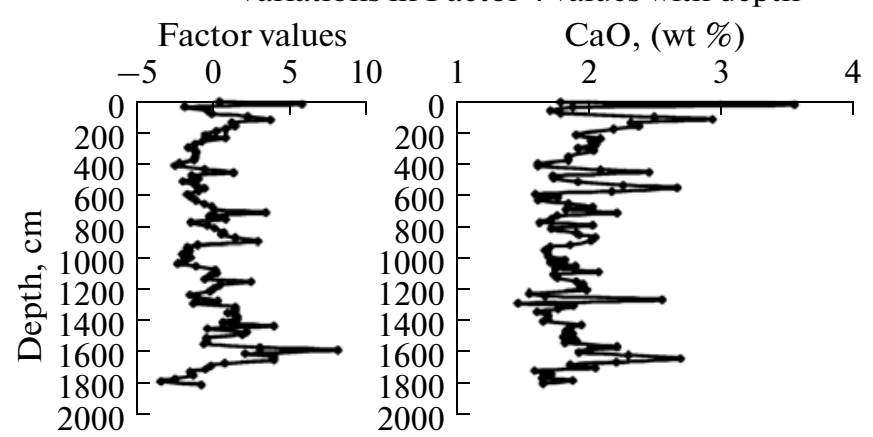

Fig. 7. Relationship between variations in the main factors controlling the distribution of major elements and components with depth.

interstadial of MIS 3. The average sedimentation rate for members 1 and 3 is about $15 \mathrm{~cm} / \mathrm{kyr}$. It is noteworthy that sedimentation rates were lowest (about $3 \mathrm{~cm} / \mathrm{kyr}$ ) during the last interglacial (MIS 5e), which was caused by Yukon sediment transport to the Arctic Ocean as well as a sharp base level rise.

The above results lead to the sound conclusion that all of these samples (except for those from the sandy 

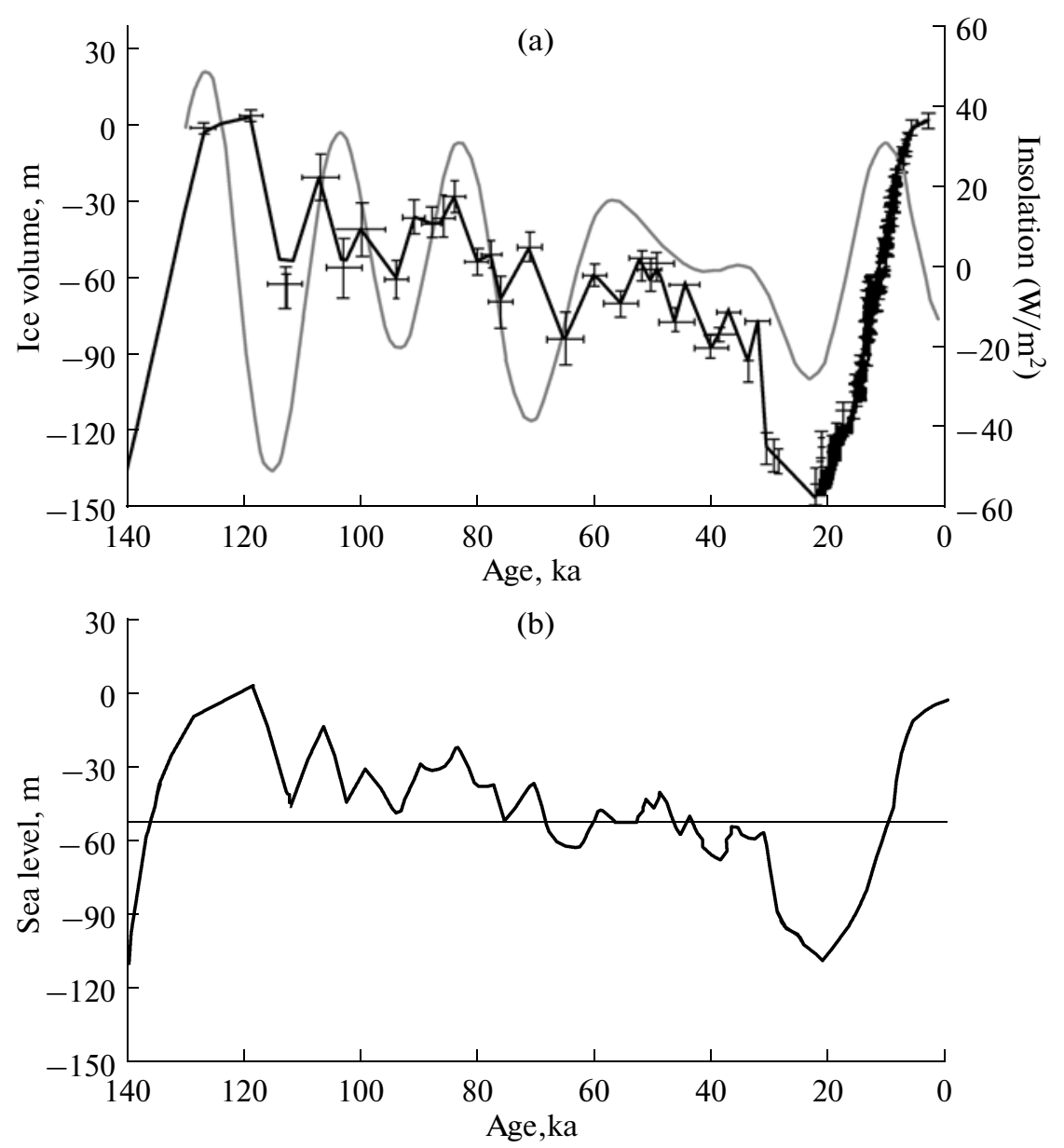

Fig. 8. Changes in ice volume in the Northern Hemisphere proxied by variations in sea-level in meters (grey line), July insolation at $65^{\circ} \mathrm{N}$ (black line), and sea level [45].

interval) were derived from the Yukon-Tanana terrane and transported by the Yukon River across Beringia. The available literature data [30] suggest that the major sediment supply to areas near the Aleutians in the Pacific was from Alaska during Late Pleistocene cold periods and from Asia and Aleutians during interglacials.

Geochronological constraints on sedimentological events. Since our grain-size record begins (from top to bottom) from the sample at $34-35 \mathrm{~cm}$, it does not reflect the first peak of magnetic susceptibility at 0 $14 \mathrm{~cm}$. Based on the data from Table 1, its age may roughly correspond to Heinrich event $\mathrm{H} 0$ (ages of these events were taken from $[4,31])$. Note that Heinrich events are periods of extensive iceberg melting in the North Atlantic and deposition of icebergrafted debris [31]. The subsequent peaks of the $>0.063-\mathrm{mm}$ size fraction at 124 and $233 \mathrm{~cm}$ correspond to $\mathrm{H} 1$ and $\mathrm{H} 2$. Maxima at 320, 454, 754, 854, and $1500 \mathrm{~cm}$ cannot be correlated with the available geochronological data because of their poor accuracy (Table 1). Therefore, some of the sand maxima in member 1 correlate with the deposition of icebergrafted debris in the North Atlantic (Heinrich events), whereas other maxima may reflect either the local deposition of ice-rafted debris in bottom sediments or the lack of precise geochronological control. The sand maxima of member 2 have no correlation with sea-ice and iceberg activity, and such maxima are absent in member 3 .

A sharp increase in bottom current intensity is reliably identified only at $74 \mathrm{~cm}$ during the deglaciation of MIS 2. The second reliable increase can be related to the interstadial of MIS 3a, and the strong increase of current influence coincides with MIS 5a-d and MIS 6.

Relatively high paleoproductivity near the Shirshov Ridge was recorded during the last deglacial period of MIS 2 (especially for the Bölling-Alleröd warm event) and two episodes during the Last Interglacial, i.e. MIS 5e. Even higher primary production is inferred for the Holocene [8, 10]. In general, higher productivity during interglacials is characteristic of the Arctic and Subarctic regions [32]. Deposition in the oxygen mini- 


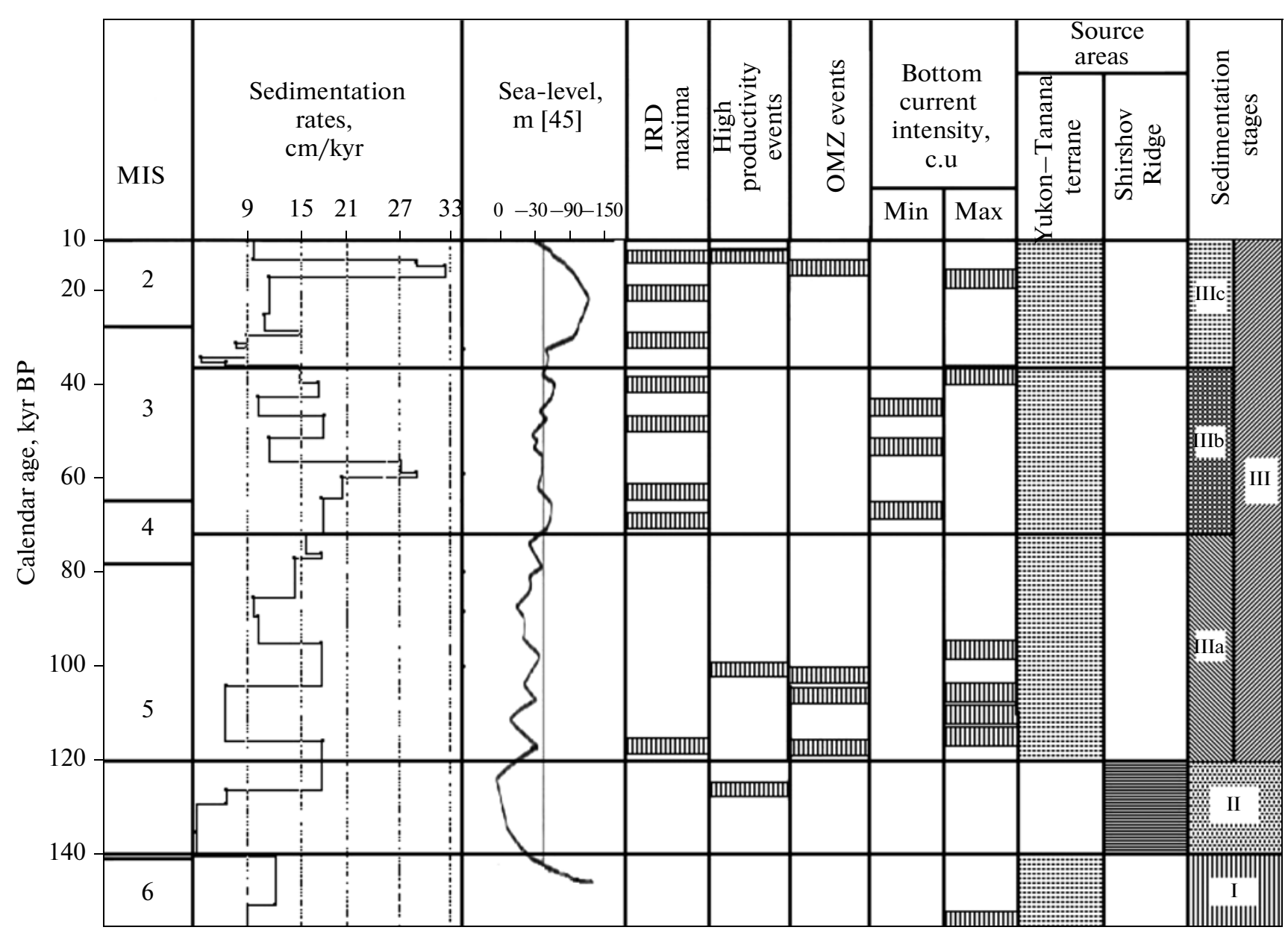

Fig. 9. Reconstruction of the Pleistocene sedimentary history of the Shirshov Ridge.

mum zone took place synchronously with the increase in paleoproductivity.

Figure 8 shows relationships between the June insolation at $65^{\circ} \mathrm{N}$, Northern Hemisphere ice volume (Fig. 8a), and inferred sea-level variations in the Bering Sea (Fig. 8b) for the past 140 kyr. The analysis of these data suggests that the major climate changes were driven by insolation changes, and the history of Northern Hemisphere glaciation was a major control on glacioeustatic sea-level fluctuations.

Intervals with the highest smectite abundance (with chlorite/smectite ratio less than 1.0) may reflect the maximum supply of altered volcanic products, which roughly corresponds to MIS 5d-MIS 3 . In this case, the oldest interval corresponds to an episode of MIS 5d, and the youngest interval corresponds to an episode of MIS 3 [33]. The highest illite abundance and illite/chlorite ratio in the three upper samples (Fig. 4) correspond to Termination 1a (deglacial of MIS 2) [11].

\section{CONCLUSIONS}

Our results suggest that the sedimentation history of the Shirshov Ridge (Fig. 9) was dominated by low sea levels over the last 156 kyr. During this time, the lowest sea level, roughly corresponding to Substage IIIc, exposed much of the continental shelf, and the Bering Strait did not exist. This dry land is called Beringia [34]. During MIS 2 and 4, in some places of Kamchatka, Koryakia [35], Chukchi Peninsula, and Alaska [36], glaciers may have advanced to the present coastline of the Bering Sea. This has been a much disputed issue, and most authors suggest that there is no evidence that glaciers have ever extended far across Kamchatka, Koryakia, and Chukchi Peninsula and that a Beringia ice sheet has ever existed during glaciations [37-40]. Rivers currently draining into the Bering Sea, first of all Yukon, spread out over the exposed shelf area far beyond their modern deltas and estuaries. For example, 16-11 ka paleo-Yukon sediments were described on a shoal located southward from St. Lawrence Island on the Bering Sea shelf [41]. The Yukon River, which carried the suspended sediment load formed mainly by the 
erosion of Paleozoic rocks within the Yukon-Tanana terrane, previously entered the Bering Sea near the Shirshov Ridge. The terrigenous material was supplied by the Yukon River to its mouth and further transported by a strong surface current (which also exists at present) over the continental slope and further in the WNW direction. This material was transported to the northern part of the Shirshov Ridge, where it partly accumulated in sediments.

During much of that period, the sea level was well below the present level but slightly above the bottom of the Bering Strait (Fig. 9); therefore, large shelf areas were under the sea. This corresponds to substages IIIb (mean sea-level) and IIIa and Stage I (sea-level highstand). As was previously shown, that time was dominated by the deposition of Yukon terrigenous materials on the Shirshov Ridge. Therefore, this material was transported along the shelf under water by the paleoYukon River. A similar situation exists at present, for instance, in the $\mathrm{Ob}$-Yenisey shoal of the Kara Sea within the $\mathrm{Ob}$ and Yenisey paleo-valleys [3], on the Laptev Sea shelf within the paleo-valleys of the Khatanga, Lena, and Yana rivers [42], as well as in many other shelf areas worldwide. Moreover, the proposed scenario clearly suggests that no active connection existed between the Bering Sea and the Arctic Ocean. Otherwise, much of the Yukon sedimentary load, like at present (Fig. 1), would have been transported through the Bering Strait by northward- and northwestwardflowing longshore currents. This scenario was recorded in the sediments of Stage II, when much of the Yukon sediments were transported into the Arctic Ocean during the Last Interglacial, which was reflected in much lower sedimentation rates and changes in the chemical and mineralogical compositions of sediments.

On the ridge slope, the clay fraction was washed out from the sediments by permanent bottom currents. The major portion of the material was supplied to the bottom from catchment areas, which was primarily controlled by glacial history and sea-level fluctuations. In both cases, cyclic climate variations were the main reason.

During the maximum lowstand, the land area was a tundra-covered alluvial plain [34], and drifting ice, probably of the pack type, existed in the northern part of the sea, which is indicated by the data of [20] for MIS 4 and MIS 2. Icebergs were most likely absent here, although for Koryakia located close to the Shirshov Ridge, although the possibility of iceberg drift to the Bering Sea during the MIS 4-3 last glacial and MIS 2 was advocated by some authors [35]. The input of icerafted debris to the sediment was probably related to sea ice melting. Similar observations were previously reported in the Sea of Okhotsk [3, 43]. The coarse size (sand and gravel) indicates that the ice-rafted debris was mostly transported by one-year ice, in particular fast ice. The synchrony of North Atlantic Heinrich events and ice-rafted debris maxima was observed in the Sea of Okhotsk [4], but they are only partly synchronous in the cored section from the Shirshov Ridge. In addition to the atmospheric teleconnections transmitting climate signals over very long distances in the Northern Hemisphere, of particular importance are specific regional features of ice regime, which are still poorly known.

Increases in primary productivity typical of interglacials and interstadials in the Arctic and Subarctic [3, 20] led to an extension of the oxygen minimum zone, which was reflected in the geochemistry of sediments. It is likely that an offshore seasonal sea ice either existed in the northern deep water part of the sea (as in Recent times) or did not exist at all. This issue requires further examination.

Sediments deposited during Substage IIIa are typically of dark grey color, clearly seen in the Arctic and Subarctic marine sediments, and have proximal sources located in areas with extensive continental ice sheets [3, $14,15]$. This observation is in agreement with our suggestion about the Yukon-Tanana terrane as the major source area, where the extensive MIS4-3 glacial in the Central Alaska took place [38]. Variations of the terrigenous fluxes were partially driven by bottom current intensity (Fig. 9). Episodes of slower currents typical of glacial periods are recorded during Substage IIIb. During Substage IIIc, fluctuations in the terrigenous fluxes appear to be largely controlled by mountain glaciation. The extent of glaciation in Alaska at the Last Glacial Maximum was $727800 \mathrm{~km}^{2}$ compared with the $74700 \mathrm{~km}^{2}$ of modern mountain glaciers [38].

Our results suggest that the Late Pleistocene sedimentary history of the Shirshov Ridge was essentially controlled by climate oscillations, which were crucial for the evolution of the Alaskan glaciation and glacioeustatic sea level change. The latter, in turn, affected relations of sea and land over the vast area of the northern Bering Sea shelf.

\section{ACKNOWLEDGMENTS}

The first author (M.L. Levitan) thanks A.G. Matul' for providing KALMAR samples of bottom sediments for this study. This study was supported by the Russian Foundation for Basic Research (project no. 11-05-00356).

\section{REFERENCES}

1. A. P. Lisitsin, Recent Sedimentation in the Bering Sea (Nauka, Moscow, 1966) [in Russian].

2. A. N. Sukhov, V. D. Chekhovich, A. V. Lander, S. L. Presnyakov, and E. N. Lepekhina, "Age of the Shirshov Sub- 
marine Ridge Basement (Bering Sea) Based on the Results of Investigation of Zircons Using the U-Pb SHRIMP Method," Dokl. Earth Sci. 439 (2), 926-932 (2011).

3. M. A. Levitan, Yu. A. Lavrushin, and R. Stein, Reviews of the Sedimentation History in the Arctic Ocean and Subarctic Region for the Last 130 kyr (GEOS, Moscow, 2007) [in Russian].

4. S. A. Gorbarenko, N. Harada, M. I. Malakhov, Y. P. Vasilenko, A. A. Bosin, and E. L. Goldberg, "Orbital and Millennial-Scale Environmental and Sedimentological Changes in the Okhotsk Sea during the Last 350 kyr," Glob. Planet. Change 72, 79-85 (2010).

5. E. Sakshaug, "Primary and Secondary Production in the Arctic Seas," in The Arctic Ocean Organic Carbon Cycle: Present and Past, Ed. by R. Stein and R. W. MacDonald (Springer, Berlin, 2004), pp. 57-82.

6. SO201-KALMAR Leg 2 Cruise Report, Ed. by C. Dullo, B. Baranov, and C. van den Bogaard (IFM-GEOMAR, Kiel, 2009).

7. S. Gorbarenko, "Stable Isotope and Lithological Evidence of Late-Glacial and Holocene Oceanography of the Northwestern Pacific and Its Marginal Seas," Quat. Res. 46, 230-250 (1996).

8. M. Cherepanova, S. Gorbarenko, M. Malakhov, and D. Nürnberg, "Diatom Stratigraphy and Paleogeography of the Western Bering Sea over the Past $170 \mathrm{ka}$," in KALMAR Workshop Program and Abstracts, (IFMGEOMAR, Trier, 2011), pp. 31-32.

9. M. Malakhov, S. Gorbarenko, D. Nürnberg, R. Tiedemann, G. Malakhova, and J.-R. Riethdorf, "Geomagnetic Relative Paleointensity of Sediment Cores of the Western Bering Sea and NW Pacific," in KALMAR Workshop Program and Abstracts (IFM-GEOMAR, Trier, 2011), p. 83.

10. E. Ovsepyan, E. Ivanova, I. Murdmaa, T. Alekseeva, and A. Bosin, "Glacial-Interglacial Environmental Changes on the Shirshov Ridge, Western Bering Sea: Micropaleontological and Sedimentary Records from Core SO 201-2-85 KL," in KALMAR Workshop Program and Abstracts (IFM-GEOMAR, Trier, 2011), pp. 89-91.

11. J.-R. Riethdorf, "Late Pleistocene to Holocene Changes in Upper-Ocean Stratification and Its Impact on Marine Productivity, Sea Surface Temperatures, and Salinity in the Subarctic Northwest Pacific," Ph. D. Thesis. (GEOMAR, Kiel, 2012).

12. P. Biscaye, "Mineralogy and Sedimentation of Recent Deep-Sea Clay in the Atlantic Ocean and Adjacent Seas and Oceans," Geol. Soc. Am. Bull. 76, 803-832 (1965).

13. M. A. Levitan, I. A. Roshchina, and A. V. Tolmacheva, "Geochemical Features of Sediments on the Continental Slope of the Weddell Sea and Their Paleoceanographic Interpretation," Lithol. Miner. Resour. 43 (2), $111-124$ (2008).

14. M. A. Levitan, I. A. Roshchina, V. Yu. Rusakov, K. V. Syromyatnikov, and R. Spielhagen, "Quaternary History of Sedimentation on the Submarine Lomonosov Ridge, North Arctic Ocean," in Structure and Evolution of the Lithosphere, Ed. by Yu. G. Leonov (Paulsen Editions, Moscow-St. Petersburg, 2010), pp. 464-490 [in Russian].

15. M. A. Levitan, I. A. Roshchina, V. Yu. Rusakov, K. V. Syromyatnikov, and R. Spielhagen, "History of Sedimentation on the Submarine Continental Margin of the Kara Sea over the Last 190 ka," in Geology and Geoecology of the Eurasian Continental Margins, Ed. by Yu.A. Lavrushin (GEOS, Moscow, 2010), Vol. 2, pp. 174-198 [in Russian].

16. V. G. Shlykov, X-Ray Analysis of Mineral Composition of Dispersed Sois (GEOS, Moscow, 2006) [in Russian].

17. D. A. Darby, A. S. Naidu, T. C. Mowatt, and G. A. Jones, "Sediment Composition and Sediment Processes in the Arctic Ocean," in The Arctic Seas: Climatology, Oceanography, Geology, and Biology, Ed. by Y. Herman (VanNostrand Reinhold, New York, 1989), pp. 657-720.

18. F. C. Moser and J. R. Hein, "Distribution of Clay Minerals in the Suspended and Bottom Sediments from the Northern Bering Sea Shelf Area," US Geol. Surv. Bull., No. 1624 (2008).

19. C. Müller, "Rekonstruktion der Palao-Umweltbedingungen am Laptev-See-Kontinentalrand wahrend der beiden letzten Glazial/Interglazial-Zyclen anhand sedimentologischer und mineralogischer Untersuchungen," Ber. Polarforsch., No. 328 (1999).

20. C. Sancetta, L. Heusser, L. Labeyrie, S. A. Naidu, and S. W. Robinson, "Wisconsin-Holocene Paleoenvironment of the Bering Sea: Evidence from Diatoms, Pollen, Oxygen Isotopes and Clay Minerals," Mar. Geol. 62, 55-68 (1985).

21. H. Champley, Clay Sedimentology (Springer, New YorkBerlin, 1989).

22. C. Dusel-Bacon, "Metamorphic History of Alaska," in The Geology of Alaska, Ed. by G. Plafker and H. C. Berg (Geol. Soc. Am., Boulder, 1994), pp. 495-534.

23. E. J. Moll-Stalcup, "Latest Cretaceous and Cenozoic Magmatism in Mainland Alaska," in The Geology of Alaska, Ed. by G. Plafker and H. C. Berg (Geol. Soc. Am., Boulder, 1994), pp. 589-620.

24. H. L. Foster, T. E. C. Keith, and W. D. Menzie, "Geology of the Yukon-Tanana Area of East Central Alaska," in The Geology of Alaska, Ed. by G. Plafker and H. C. Berg (Geol. Soc. Am., Boulder, 1994), pp. 205-240.

25. A. B. Ronov, A. A. Yaroshevskii, and A. A. Migdisov, Chemical Structure of the Earth's Crust and Geochemical Balance of Major Elements (Nauka, Moscow, 1990) [in Russian].

26. The Geology of Alaska, Ed. by G. Plafker and H. C. Berg (Geol. Soc. Am., Boulder, 1994).

27. Th. E. Moore, W. K. Wallace, K. J. Bird, S. M. Karl, Ch. G. Mull, and J. T. Dillon, "Geology of Northern Alaska," in The Geology of Alaska, Ed. by G. Plafker and H. C. Berg (Geol. Soc. Am., Boulder, 1994), pp. 49-140.

28. M. A. Levitan, M. V. Bourtman, L. L. Demina, V. V. Krupskaya, E. M. Sedykh, and M. Yu. Chudetskii, "History of Holocene Sedimentation in the Southern Kara Sea," Lithol. Miner. Resour. 39 (6), 566-579 (2004).

29. D. Gallego-Torres, F. Martinez-Ruiz, A. Paytan, F. J. Jimenez-Espejo, and M. Ortega-Huertas, "PlioceneHolocene Evolution of Depositional Conditions in the Eastern Mediterranean: Role of Anoxia Vs. Productivity at Time of Sapropel Deposition," Palaeogeography, Palaeoclimatology, Palaeoecology 209, 424-439 (2004).

30. S. Van Laningham, N. G. Pisias, R. A. Duncan, and P. D. Clift, "Glacial-Interglacial Sediment Transport to the Meiji Drift, Northwest Pacific Ocean: Evidence for 
Timing of Beringian Outwashing," Earth Planet. Sci. Lett. 277, 64-72 (2009).

31. M. Sarnthein, K. Stattegger, D. Dreger, H. Erlenkeuser, P. Grootes, B. J. Haupt, S. Jung, T. Kiefer, W. Kuhnt, U. Pflaumann, C. Schafer-Neth, H. Schulz, M. Schulz, D. Seidov, J. Simstich, S. van Kreveld, E. Vogelsang, A. Volker, and M. Weinelt, "Fundamental Models and Abrupt Changes in North Atlantic Circulation and Climate over the Last $60 \mathrm{ky}$-Concepts, Reconstruction, and Numerical Modeling," in The Northern North Atlantic: A Changing Environment (Springer, Berlin, 2001), pp. $365-410$.

32. M. A. Levitan and Yu. A. Lavrushin, Sedimentation History in the Arctic Ocean and Subarctic Seas for the Last 130 kyr (Springer, Berlin, 2009).

33. B. J. L. Jensen, D. G. Froese, S. J. Preece, J. A. Westgate, and T. Stachel, "An Extensive Middle to Late Pleistocene Tephrochronological Record from East-Central Alaska," Quat. Sci. Rev. 27, 411-427 (2008).

34. D. M. Hopkins, "Aspects of the Paleogeography of Beringia during the Late Pleistocene," in Paleoecology of Beringia (Academic Press, New York, 1982), pp. 3-28.

35. G. R. Bigg, C. D. Clark, and A. L. C. Hughes, "A Last Glaciation Sheet on the Pacific Russian Coast and Catastrophic Change Arising from Coupled Ice-Volcanic Interaction," Earth Planet. Sci. Lett. 265, 559-570 (2008).

36. T. D. Hamilton, "Late Cenozoic Glaciation of Alaska," in The Geology of Alaska, Ed. by G. Plafker and H. C. Berg (Geol. Soc. Am., Boulder, 1994), pp. 813844.

37. V. S. Pushkar and M. V. Cherepanova, "Beringia: Impact of Paleoclimates of Northeast Asia and North Pacific during Last Pleistocene Glaciation," Quat. Int. 237, 3238 (2011).

38. D. S. Kaufman and W. F. Manley, "Pleistocene Maximum and Late Wiskonsian Glacier Extends across Alaska, USA," in Quaternary Glaciations_Extent and
Chronology, Ed. by J. Ehlers and P. L. Gibbard (Elsevier, Amsterdam, 2004), pp. 9-27.

39. J. Brigham-Grette, L. M. Gualtieri, O. Yu. Glushkova, T. D. Hamilton, D. Mostoller, and A. Kotov, "Chlorine36 and ${ }^{14} \mathrm{C}$ Chronology Support a Limited Last Glacial Maximum across Chukotka, North-Eastern Siberia, and No Beringian Ice Sheet," Quat. Res. 59, 386-398 (2003).

40. G. Stauch and L. Gualtieri, "Late Quaternary Glaciations in Northeastern Russia," J. Quat. Sci. 23, 545-558 (2008).

41. H. J. Knebel and J. S. Creager, "Yukon River: Evidence for Extensive Migration during the Holocene Transgression," Science 179, 1230-1232 (1973).

42. H. Bauch, H. Kassens, H. Erlenkeuser, P. M. Grootes, and J. Thiede, "Depositional Environment of the Laptev Sea (Arctic Siberia) during the Holocene," Boreas 28, 194-204 (1999).

43. S. A. Gorbarenko, J. R. Southon, L. D. Keigwin, M. V. Cherepanova, and I. G. Gvozdeva, "Late Pleistocene-Holocene Oceanographic Variability in the Okhotsk Sea: Geochemical, Lithological and Paleontological Evidence," Palaeogeography, Palaeoclimatology, Palaeoecology 209, 281-301 (2004).

44. G. D. Sharma, The Alaskan Shelf. Hydrographic, Sedimentary and Geochemical Environment (Springer-Verlag, New York-Heidelberg-Berlin, 1979).

45. A. Hu, G. A. Meehl, B. L. Otto-Bliesner, C. Waelbroeck, W. Han, M. -F. Loutre, K. Lambeck, J. X. Mitrovica, and N. Rosenbloom, "Influence of Bering Strait Flow and North Atlantic Circulation on Glacial-Sea Level Changes," Nature Geosci. 3, 118-121 (2010).

46. P. J. Stabeno and R. K. Reed, "Circulation in the Bering Sea Observed by Satellite-Tracked Drifters: 19861993," J. Phys. Oceanogr. 24 (4), 840-854 (1994).

47. Ya. E. Yudovich and M. P. Ketris, Principles of Lithochemistry (Nauka, St. Petersburg, 2000) [in Russian]. 